International Journal of Machine Consciousness 4 (June 2012): 109-140

\title{
NON-DESTRUCTIVE WHOLE-BRAIN MONITORING USING NANOROBOTS: NEURAL ELECTRICAL DATA RATE REQUIREMENTS
}

\author{
NUNO R. B. MARTINS \\ Centre of Mathematics \\ Guimarães, 4800-058, Portugal \\ n-martins@n-martins.com \\ WOLFRAM ERLHAGEN \\ Centre of Mathematics \\ Guimarães, 4800-058, Portugal \\ Wolfram.erlhagen@math.uminho.pt \\ ROBERT A. FREITAS JR. \\ Institute for Molecular Manufacturing, 555 Bryant Street, Suite 354 \\ Palo Alto, California 94301, USA \\ rfreitas@rfreitas.com
}

Neuronanorobotics, a promising future medical technology, may provide the ultimate tool for achieving comprehensive non-destructive real-time in vivo monitoring of the many information channels in the human brain. This paper focuses on the electrical information channel and employs a novel electrophysiological approach to estimate the data rate requirements, calculated to be $(5.52 \pm 1.13) \times 1016 \mathrm{bits} / \mathrm{sec}$ in an entire living human brain, for acquiring, transmitting, and storing singleneuron electrical information using medical nanorobots, corresponding to an estimated synapticprocessed spike rate of $(4.31 \pm 0.86) \times 1015$ spikes/sec.

Keywords: human brain information; medical nanorobotics; nanomedicine; nanorobot; nanotechnology; neuronanorobot; neuronanorobotics; whole-brain emulation.

Abbreviations: RS - Regular Spiking; FS - Fast Spiking; B - Bursting; SWS - Slow Wave Sleep; REM sleep - Rapid Eye Movement Sleep; LTP - Long-Term Potentiation; LTD - Long-Term Depression; ALS - Amyotrophic lateral sclerosis.

\section{Introduction}

The human brain is the only body organ that cannot, even in principle, be transplanted from a donor without fundamentally altering the individual persona of the recipient. Information pertaining to brain structure, neural connectivity, neurotransmitter activity, cellular and organ-level neurological function, and higher mental states including personality and self-awareness can be permanently altered or lost as a result of physical trauma, pathogenic diseases, and a variety of common degenerative disorders such as ALS and Alzheimer's, Huntington's and Parkinson's diseases. Once destroyed, this information cannot, even in principle, be recovered using current techniques, thus 
permanently diminishing patient health. It must be a key goal of future medical technology to provide novel methods for non-destructively acquiring, transmitting, validating, and archiving comprehensive brain-related structural and functional information. Such person-specific information, once preserved, might subsequently be employed to analyze existing pathologies at cellular detail and to devise appropriate therapies, and ultimately might be used to guide processes designed to restore the original state of the brain that existed prior to its pathological degradation.

The emerging prospect of medical nanorobotics [Freitas, 1998, 1999, 2003, 2005a,b] [Morris, 2001] [Astier et al., 2005] [Patel et al., 2006] [Park et al., 2007] [Popov et al., 2007] [Martel et al., 2009] [Mallouk and Sen, 2009] [Kostarelos, 2010] [Mavroides and Ferreira, 2011] offers an ideal technology for monitoring, recording, and even manipulating many different types of brain-related information. This paper previews a proposed new medical technology called neural nanorobotics or neuronanorobotics. Medical neuronanorobots may be capable of real-time monitoring of single-neuron neuroelectric activity, local neuropeptide traffic, and other relevant functional data, and may also be able to acquire relevant structural information including neuron surface features and connectome mapping [Sporns, 2005][Lu, 2009][Anderson, 2011][Kleinfeld, 2011][Seun, 2011] in a living brain. Non-destructive whole-brain monitoring would be enabled by the coordinated activities of large numbers of cooperating neuronanorobots. When coupled with single-cell repair capabilities [Freitas, 2007], advanced medical neuronanorobotics provides the ultimate technology needed to treat Parkinson's and Alzheimer's diseases, other brain-related neurodegenerative disorders, epilepsy, dementia, memory and sensory disorders, spinal cord and neuromuscular disorders, pain and toxic disorders, and a wide variety of traumatic injuries to the brain.

The advent of medical nanorobotics requires the ability to build nanorobotic devices and to produce these devices in sufficient therapeutic quantities to treat individual patients. The most advanced medical nanorobots will likely be fabricated using diamondoid materials, as these materials provide the greatest strength, durability, and reliability in the in vivo environment [Freitas, 2010]. Designs for a wide variety of medical nanorobots have been proposed [Freitas, 1998, 2000, 2002, 2005c, 2006a, 2007] and additional details are available elsewhere [Freitas, 2005b, 2006b, 2010]. The practical technical foundation for advanced medical nanorobotics requires answering a fundamental question: how to build diamondoid nanorobots, starting from current manufacturing technologies? The answer to this question is the main subject of an ongoing international collaboration whose principal objective is the construction of a nanofactory capable of mass-manufacture of medical diamondoid nanorobotic devices for medical treatments [Freitas and Merkle, 2006] [Freitas 2010]. Possible general methods to achieve massively parallel molecular manufacturing technologies, such as a nanofactory, have been reviewed in the literature [Freitas and Merkle, 2004], and methods for controlling individual and large numbers of medical nanorobots are also the subject of current research [Cavalcanti and Freitas, 2003] [Cavalcanti et al., 2008] 
[Freitas, 2009]. The present work assumes that these manufacturing challenges can be overcome.

An ongoing $\mathrm{PhD}$ thesis effort is investigating the potential feasibility of real-time non-destructive whole-brain in vivo monitoring of the many information channels of a human brain, in particular single-neuron electrical information, local neuropeptide traffic, and other relevant functional data. A comparison of the whole-brain data rate monitoring requirement with the theoretical capabilities of medical neuronanorobotics is the first step in assessing the viability of this future technology. The present work focuses on the electrical information channel and calculates the data rate requirements for acquiring, transmitting, and storing single-neuron electrical information from an entire human brain, summing estimates of bit rates and spiking rates for neurons in the main sub-regions of the human brain using a novel electrophysiological-based estimation procedure.

\section{Neural Electrical Data Processing in the Human Brain}

Previous estimates of human brain electrical data processing rates have ranged from a low of $1.48 \times 10^{11} \mathrm{bits} / \mathrm{sec}$ to a high of $3.2 \times 10^{29} \mathrm{bits} / \mathrm{sec}$ using a wide variety of assumptions and constraints not all of which are directly comparable, as summarized in ascending order in Table 1.

Table 1. Previous estimates of the electrical processing capacity of the whole human brain (partially adapted from [Sandberg, 2008]).

\begin{tabular}{|c|c|c|}
\hline $\begin{array}{l}\text { Author } \\
\text { (Year) }\end{array}$ & $\begin{array}{l}\text { Est. Processing Rate of the } \\
\text { Whole Human Brain } \\
\text { (bits/sec) }\end{array}$ & Key Assumptions and Notes \\
\hline $\begin{array}{l}\text { von } \\
\text { Neumann } \\
(1958)\end{array}$ & $\begin{array}{l}\text { Whole human brain } \\
\text { processing rate of } 1.48 \times 10^{11} \\
\text { bits/second [von Neumann, } \\
\text { 1958]. }\end{array}$ & $\begin{array}{l}\text { von Neumann considered that all neural impulses } \\
\text { conducted in the human brain during a human lifetime } \\
\text { of } 60 \text { years are equivalent to } 2.8 \times 10^{20} \text { bits. }\end{array}$ \\
\hline $\begin{array}{l}\text { Seitz } \\
(2007)\end{array}$ & $\begin{array}{l}\text { Whole human brain } \\
\text { processing rate of } 2 \times 10^{18} \\
\text { synaptic updates/second } \\
\text { [Seitz, 2007]. }\end{array}$ & $\begin{array}{l}\text { Seitz assumed between } 0.5 \times 10^{11} \text { and } 2 \times 10^{11} \text { neurons, } \\
\text { between } 10^{3} \text { and } 10^{5} \text { synapses per neuron, and an } \\
\text { average of } 200 \text { spikes/neuron/second. }\end{array}$ \\
\hline $\begin{array}{l}\text { Seitz } \\
(2007)\end{array}$ & $\begin{array}{l}\text { Whole human brain } \\
\text { processing rate of } 20 \times 10^{15} \\
\text { cups (connection-updates- } \\
\text { per-second) assuming } 10^{4} \\
\text { synapses per neuron [Seitz, } \\
\text { 2007]. }\end{array}$ & $\begin{array}{l}\text { Seitz estimated the processing power of the human } \\
\text { visual cortex. Assuming that the visual cortex had } 6 \times 1 \\
10^{9} \text { neurons each firing } 40 \text { times per second, Seitz } \\
\text { concluded that the processing capacity of the visual } \\
\text { cortex was } 240 \times 10^{9} \text { spikes/sec. Assuming that the } \\
\text { visual cortex had } 5 \times 10^{13} \text { synapses (assuming } \sim 15,000 \\
\text { interconnections per neuron), and assuming } 40 \\
\text { spikes/neuron-sec, he estimated that the visual cortex } \\
\text { would perform } 2 \times 10^{15} \text { connection updates per second } \\
\text { or, as he puts it, } 2 \text { Pcups (peta-connection-updates-per- }\end{array}$ \\
\hline
\end{tabular}


sec).

\begin{tabular}{|c|c|c|}
\hline $\begin{array}{l}\text { Merkle } \\
(1989)\end{array}$ & 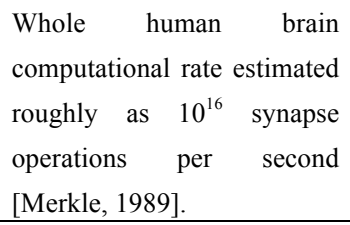 & $\begin{array}{l}\text { Merkle assumed roughly } 10^{15} \text { synapses operating at } \\
\text { about } 10 \text { impulses/second. }\end{array}$ \\
\hline $\begin{array}{l}\text { Merkle } \\
(1989)\end{array}$ & $\begin{array}{l}\text { Whole human brain } \\
\text { computational rate estimated } \\
\text { between } 10^{12} \text { and } 10^{14} \\
\text { operations per second } \\
\text { [Merkle, 1989]. }\end{array}$ & $\begin{array}{l}\text { Merkle estimated also that the retina as a whole } \\
\text { performs about } 10^{10} \text { analog adds per second and so, } \\
\text { multiplying this estimate by the ratio of brain size to } \\
\text { retinal size he arrived at the estimate of } 10^{12} \text { and } 10^{14} \\
\text { operations per second as the computational power of } \\
\text { the human brain. }\end{array}$ \\
\hline $\begin{array}{l}\text { Moravec } \\
(1998)\end{array}$ & $\begin{array}{l}\text { Whole human brain } \\
\text { computational rate } \sim 10^{14} \\
\text { FLOPS. [Moravec, 1998] }\end{array}$ & $\begin{array}{l}\text { Moravec estimates the visual computational } \\
\text { processing power of the human retina as being } 1000 \\
\text { MIPS. Then, assuming a } 1,500 \text { cubic centimeter human } \\
\text { brain, explains that the human brain is approximately } \\
100,000 \text { times as large as the retina, thus concludes } \\
\text { estimating that the processing power of the human } \\
\text { brain is } 100 \text { million MIPS. }\end{array}$ \\
\hline $\begin{array}{l}\text { Merkle } \\
(1989)\end{array}$ & $\begin{array}{l}\text { Whole human brain } \\
\text { computational rate estimated } \\
\text { as } 2 \times 10^{15} \text { synapse ops per } \\
\text { second [Merkle, 1989]. }\end{array}$ & $\begin{array}{l}\text { Merkle estimated the total energy used by the brain } \\
\text { each second, then divided it by the energy used for each } \\
\text { basic operation to conclude that a } 10 \text { watt brain can do } \\
\text { at most } 2 \times 10^{15} \text { synapse operations per second. } \\
\text { Merkle's } 3 \text { different estimates put the human brain raw } \\
\text { computational power between } 10^{13} \text { and } 10^{16} \text { operations } \\
\text { per second. }\end{array}$ \\
\hline $\begin{array}{l}\text { Sarpeshka } \\
\text { (1998) }\end{array}$ & $\begin{array}{l}\text { Whole human brain } \\
\text { processing rate estimated as } \\
3.6 \quad \times \quad 10^{15} \text { synaptic } \\
\text { operations per } \quad \text { second } \\
\text { [Sarpeshka, } 1997,1998] .\end{array}$ & $\begin{array}{l}\text { Sarpeshka argues that there are about } 2.4 \times 10^{14} \\
\text { synapses in each cortex of the brain, with an average } \\
\text { firing rate (at the cortex) of } 7.5 \mathrm{~Hz} \text { (between } 5-10 \mathrm{~Hz} \text { ). } \\
\text { He observes that he is assuming that each synapse is } \\
\text { always operational and constantly computing. He } \\
\text { concludes that the number of synaptic operations per } \\
\text { second is } 2 \times 2.4 \times 10^{14} \times 7.5=3.6 \times 10^{15} \text {. }\end{array}$ \\
\hline $\begin{array}{l}\text { Kurzweil } \\
(1999)\end{array}$ & $\begin{array}{l}\text { Whole human brain } \\
\text { processing rate estimated as } \\
2 \times 10^{16} \text { FLOPS (64 } \times 10^{16} \\
\text { bits/sec, assuming single- } \\
\text { precision) [Kurzweil, 1999]. }\end{array}$ & $\begin{array}{l}\text { Kurzweil assumed } 10^{11} \text { neurons, } 10^{3} \text { synapses per } \\
\text { neuron and } 200 \text { operations per second. Kurzweil puts it } \\
\text { as a "conservatively high estimate". }\end{array}$ \\
\hline $\begin{array}{l}\text { Dix } \\
(2005)\end{array}$ & $\begin{array}{l}\text { Whole human brain } \\
\text { processing rate estimated as } \\
10^{16} \text { synaptic ops/second (or } \\
10 \text { peta-nuop per second; }\end{array}$ & $\begin{array}{l}\text { Dix assumed } 10^{10} \text { neurons and } 10^{4} \text { synaptic operations } \\
\text { per cycle, and } 100 \mathrm{~Hz} \text { cycle time. It is worth noting that } \\
\text { Dix calls his estimates "back of the envelope } \\
\text { calculations". }\end{array}$ \\
\hline
\end{tabular}


Non-destructive whole-brain monitoring using nanorobots: neural electrical data rate requirements

nuop $=$ neural operations per

second) [Dix, 2007].

\begin{tabular}{|c|c|c|}
\hline $\begin{array}{l}\text { Malickas } \\
\text { (1996) }\end{array}$ & $\begin{array}{l}\text { Whole human brain } \\
\text { processing rate estimated } \\
\text { between } 10^{15}-10^{18} \text { synaptic } \\
\text { operations per } \\
\text { [Malickas, 1996]. }\end{array}$ & $\begin{array}{l}\text { Malickas observes that Merkle estimates a lower value, } \\
\text { between } 10^{13} \text { and } 10^{16} \text { synaptic operations per second. }\end{array}$ \\
\hline $\begin{array}{l}\text { Bostrom } \\
\text { (1998) }\end{array}$ & $\begin{array}{l}\text { Whole human brain } \\
\text { processing rate estimated as } \\
10^{17} \text { operations per second } \\
\text { [Bostrom, 1998] }\end{array}$ & $\begin{array}{l}\text { Bostrom assumed } 10^{11} \text { neurons, } 5 \times 10^{3} \text { synapses and } \\
\text { synapses firing at } 100 \mathrm{~Hz} \text {, with each signal using } 5 \text { bits. } \\
\text { Bostrom emphasizes that his estimate must be a } \\
\text { maximum value given redundancy of information in the } \\
\text { brain, and illustrates with a previous estimate from } \\
\text { Moravec of } 10^{14} \text { FLOPS (or } 32 \text { x } 10^{14} \text { bits/sec). } \\
\text { Bostrom observes that these estimates refer to what he } \\
\text { believes is the minimal amount of computation } \\
\text { necessary to replicate the chemical and electrodynamic } \\
\text { features of the neuronal response function that is } \\
\text { relevant for the total performance of the neural net. He } \\
\text { notes that the degree of detail necessary to replicate the } \\
\text { individual neuron and brain performance is unknown. }\end{array}$ \\
\hline $\begin{array}{l}\text { Fiala } \\
(2007)\end{array}$ & $\begin{array}{l}\text { Whole human brain } \\
\text { processing rate estimated as } \\
2.56 \times 10^{17} \text { bytes/second } \\
\text { [Fiala, 2007] [Sandberg, } \\
\text { 2008]. }\end{array}$ & $\begin{array}{l}\text { Fiala seems to have assumed } 10^{14} \text { synapses, with } \\
\text { identity coded by } 48 \text { bits plus }(2 \times 36) \text { bits for pre- and } \\
\text { post-synaptic neuron identity, and } 1 \text { byte for state, with } \\
\text { a } 10 \mathrm{~ms} \text { timescale. }\end{array}$ \\
\hline
\end{tabular}

\begin{tabular}{|c|c|c|}
\hline $\begin{array}{l}\text { Sandberg } \\
(2009)\end{array}$ & $\begin{array}{l}\text { Whole human brain } \\
\text { processing rate estimated as } \\
1.2 \times 10^{18} \text { FLOPS (or } 38.4 \mathrm{x} \\
10^{18} \text { bits/sec) [Sandberg, } \\
2008] .\end{array}$ & $\begin{array}{l}\text { For emulation purposes, Sandberg assumed } 10^{11} \\
\text { neurons, each with } 10^{4} \text { compartments running the } \\
\text { Hodgkin-Huxley equations with } 1200 \text { FLOPS each. } \\
\text { Each compartment would have } 4 \text { dynamical variables } \\
\text { and } 10 \text { parameters described by one byte each. }\end{array}$ \\
\hline $\begin{array}{l}\text { Thagard } \\
(2002)\end{array}$ & $\begin{array}{l}\text { Whole human brain } \\
\text { processing rate estimated as } \\
\sim 10^{23} \text { (or } 32 \times 10^{23} \text { bits } / \mathrm{sec} \text { ) } \\
\text { FLOPS [Thagard 2002]. }\end{array}$ & $\begin{array}{l}\text { Thagard speculates that the processors in the brain } \\
\text { might be the proteins and not just the neurons. He } \\
\text { assumes that one neuron influences } 10^{6} \text { brain proteins } \\
\text { via released hormones. Thagard argues also that the } \\
\text { number of processors in the brain is certainly more than } \\
\text { the } 10^{11} \text { neurons, but also notes that the processor count } \\
\text { is probably less than } 10^{17} \text { (the number of proteins in the } \\
\text { brain). }\end{array}$ \\
\hline $\begin{array}{l}\text { Hameroff } \\
(1987) \text { and } \\
\text { Penrose }\end{array}$ & & $\begin{array}{l}\text { Proposed that quantum effects may play an important } \\
\text { role in the function of the brain and that microtubule } \\
\text { network underlies consciousness [Hameroff, 1987] }\end{array}$ \\
\hline
\end{tabular}


[Penrose, 1989]. If each of the $10^{16}$ microtubules in the whole-brain neuron population stores one single qubit then the $10^{16}$ qubit system would require a classic computer with $20^{10,000,000,000,000,000}$ bits; if each neuron microtubule system acts as an isolated quantum computing network then the whole brain would have $10^{11}$ connected 100,000 qubit quantum computers [Sandberg, 2008].

\begin{tabular}{lll}
\hline $\begin{array}{l}\text { Tuszynski } \\
\text { (2006) }\end{array}$ & $\begin{array}{l}\text { Whole human brain } \\
\text { processing rate estimated as }\end{array}$ & $\begin{array}{l}\text { Assumes classical computation on microtubules. } \\
\text { Tuszunski explains that each microtubule dimer can }\end{array}$ \\
$10^{28}$ FLOPS (or $32 \times 10^{28}$ & have 32 states (four states per dimer, four states per \\
bits/sec) [Tuszynski, 2006]. & electron inside the tubulin dimer, with at least two \\
& computational states), and since there are 13 dimers per \\
& ring and 1,250 rings per midsize microtubule, then each \\
& microtubule would have 100 kilobytes of information. \\
& The known number of microtubules per neuron \\
& suggests $10^{9}$ bytes per neuron, yielding $10^{19}$ bytes per \\
& brain assuming $10^{10}$ neurons per brain. If the electrons \\
& oscillate or make transitions in this state on the order of \\
& nanoseconds, then the processing power is $10^{28}$ FLOPS \\
& (or $32 \times 10^{28}$ bits/sec).
\end{tabular}

Assessing the total neural electrical data processing activity of the human brain (that neuronanorobots must monitor) requires consideration of several key issues:

- What are the relevant cellular, sub-cellular, or molecular level processing units of electrical information of the human brain? What is the contribution of each processing unit to the processing power of the human brain? If a processing unit changes its processing behavior (e.g., when synapses change their weightings), does this influence the processing capacity of the human brain? These issues are addressed in Section 2.1.

- What relevant information is carried in each spike train and in each action potential? Does an individual action potential waveform (having shape, height and width) carry relevant information? How much information is transmitted in the temporal pattern of each spike train? The action potential waveform and not just the temporal pattern of spikes (or the average spiking rate) should be included in any analysis of information transfer by neurons since it appears that the changing subthreshold voltage on which the action potential sits is a highly relevant biophysical signal that influences information processing in pools of neurons (e.g., background-modulated pulse code). These issues are addressed in Sections 2.2 and 2.3.

- How many action potentials are generated per second in the human brain? How solidly grounded, in currently available experimental data, are the estimates of the 
average neuron spiking rates? How different are minimum, maximum, and average firing rates for neurons? How many neurons and synapses exist in the whole human brain? These issues are addressed using a novel electrophysiological approach in Sections 3 and 4 .

\subsection{Neural electrical information processing units}

There seems to be some disagreement on what should be considered a processing unit. A structural component, such as a neuron or a synapse, should be considered a processing unit if there are "relevant" changes to the input/output of action potentials that interacts with that structural component. A metric to measure the "relevance" of the changes is thus required. In the literature there is general consensus that neurons and synapses should be considered as processing units, but there is no agreement about whether dendritic trees, axons, proteins, or neural microtubules should be considered as relevant processing units.

Neurons are electrical information processing units because they receive, integrate, generate, transmit and communicate information using action potentials [Koch, 1997] [Koch and Segev, 2000] [Zhang, 2008]. Neurons receive electrical data mostly via their dendritic tree, then integrate it in the soma. Neurons then generate new information encoded in the form of action potentials in the axon hillock and axon initial segment, transmit the action potentials through the axon, and communicate the information to the next neuron cell via its synapses. In this paper we do not attempt to quantify the functional significance of these different processing stages (dendritic tree, soma, axon and synapse) in neuronal information processing [Koch, 1983] [London and Hausser, 2005] [Zador, 1998] [Juusola, 1996] [Bialek, 1993] [Manwani, 2001]. We will not attempt to quantify the neuronal noise sources and their influence on the reliability and precision of neuronal signaling [Bialek and Rieke, 1992], and we also ignore important issues like the precise quantification of the reliability of stimulus-response functions or the question of what is being encoded by spike activity.

Synapses are the key part of the neuron network that processes information and is involved in learning and memory [Xu et al., 2007] [Black et al., 1990] [Bliss and Collingridge, 1993] [IBM, 2008] [Holtmaat and Svoboda, 2009]. Synapse size and shape is reported to play a role both in long-term and short-term memory storage and deletion [Lee et al., 2008] [Kandel, 2001] [Puro et al., 1997]. Apart from being key elements for signal transduction and plasticity, synapses in most cases ensure one-way transmission of signals, allow more complex system behaviors, and slow down electrical signals [Rollenhagen and Lübke, 2006] [Rollenhagen et al., 2007]. Theoretical results have shown that the computational power of a network is increased through the use of dynamic synapses [Maas, 1999], and synapses are involved in temporal processing of information [Fuhrmann et al., 2002]. The emulation of biological synapses is considered necessary as a building block for brain-like computational systems [Kuzum et al., 2011]. 
We therefore regard synapses as the most relevant electrical processing units of the human brain*.

\subsection{Information content of individual action potential waveform}

Various types of neurons have differences in the shape, rate, and pattern of firing of action potentials [Bean, 2007] [Brenner et al., 2000]. Action potentials encode information in their shape, or waveform [Bean, 2007] [Polavieja et al., 2005]. Small differences in action potential waveform can produce changes in the timing of presynaptic calcium entry, leading to dramatic changes in the postsynaptic response [Bean, 2007]. The "typical" $\sim 20 \mu \mathrm{m}$ human neuron discharges 5-100 action potentials per second, moving from approximately $-65 \mathrm{mV}$ potential to approximately $+35 \mathrm{mV}$ potential in $\sim 10^{-3} \mathrm{sec}$. More specifically, the rising phase of an action potential reaches its peak of $+38.9 \mathrm{mV}$ in $\sim 0.592 \mathrm{~ms}$ in unmyelinated axons, then repolarizes and crosses $65 \mathrm{mV}$ at $1.3 \mathrm{~ms}$ after the peak, after reaching maximum hyperpolarization of $-77 \mathrm{mV}$ at $1.261 \mathrm{~ms}$ after the peak [Crotty, 2006].

The action potential is a localized change in $\mathrm{Na}^{+}$and $\mathrm{K}^{+}$ion concentrations and the action potential waveform depends on small changes in the timing of the $\mathrm{Na}^{+}$and $\mathrm{K}^{+}$ influx and efflux. Experimental data reports a "typical" action potential having the first peak of the $\mathrm{Na}^{+}$current occurring $100 \mu$ s before the peak of the action potential at a magnitude of $943 \mu \mathrm{A} / \mathrm{cm}^{2}$ per unit axon surface area [Crotty et al., 2006]. The falling $\mathrm{Na}^{+}$ current, at a magnitude of $35 \mu \mathrm{A} / \mathrm{cm}^{2}$, reaches equality with the rising potassium current $50 \mu$ s after the voltage peak, after which the $\mathrm{Na}^{+}$current rises to a second peak of 417 $\mu \mathrm{A} / \mathrm{cm}^{2}$ at $150 \mu \mathrm{s}$ after the action potential peak [Crotty et al., 2006]. From this second peak, the $\mathrm{Na}^{+}$current then declines over a period of about half a millisecond, approaching its rest value of $4 \mu \mathrm{A} / \mathrm{cm}^{2}$ [Crotty et al., 2006]. In the action potential the period of the net inward $\mathrm{Na}^{+}$flux has a value of $0.108 \mu \mathrm{C} / \mathrm{cm}^{2}$, which gives a flux per unit axon length of $16 \mathrm{nC} / \mathrm{cm}$ or an energy cost of $4.2 \mathrm{~nJ} / \mathrm{cm}$ [Crotty et al., 2006]. The $\mathrm{K}^{+}$current has only a single peak, which occurs $225 \mu \mathrm{s}$ after the action potential peak at a magnitude of 0.621 $\mathrm{mA} / \mathrm{cm}^{2}$. The net $\mathrm{K}^{+}$flux has a value of $0.107 \mu \mathrm{C} / \mathrm{cm}^{2}$ [Crotty et al., 2006].

Action potentials are initiated not only at the axon hillock but also at the axon initial segments ( $\sim 35 \mu \mathrm{m}$ from the axon hillock) and even at the first node of Ranvier $(\sim 90 \mu \mathrm{m}$ from the axon hillock) [Palmer and Stuart, 2006] [Palay et al., 1968]. For example, in some pyramidal neurons of cortical layer 5 action potentials are initiated at the axon initial segment [Palmer and Stuart, 2006]. The axon initial segment molecular

\footnotetext{
* For simplicity, we assume here that real-time information processing in the brain can be monitored by placing one neuronanorobot at each synaptic connection in the brain and having it record/transmit data on spiking at this local synapse, though other approaches may also be considered. It is possible that this method of collecting data might provide redundant information since thousands of synapses share a common spiking neuron, in which case the present analysis provides an upper limit to the data processing requirements of a network of nanorobots placed one per synapse, which could overestimate the overall information processing capacity of the brain. But while some synapses have a common spiking neuron, synapses are the processing units of electrical information and do not generate action potentials but instead process electrical signals, which is why measuring the spikes produced by neurons is not enough to quantify the electrical information being processed in the human brain.
} 
organization includes high densities of specialized protein complexes consisting of ion channels, CAMs, cytoskeletal and scaffolding proteins, and modulatory proteins [Ogawa and Rasband, 2008]. Among this molecular variety, the axon initial segment Kv1 potassium channels (which have a 10-fold increase in the first $50 \mu \mathrm{m}$ of the axon initial segment) control both axonal action potential waveform and synaptic efficacy [Kole et al., 2007]. Kv1 potassium channels shape the action potential waveform in the axon initial segment of layer 5 pyramidal neurons, independent of the soma [Kole et al., 2007].

Action potentials carry information (which depends on the previous $50 \mathrm{~ms}$ of conductance stimulus history) in their waveform [Polavieja et al., 2005] [Bean, 2007]. The rate of information transfer considering only action potential waveforms is estimated to be 3-4 times larger than that of the stereotyped spike train impulses (considering only the spike timing pattern) [Polavieja et al., 2005]. In one example, at a spike rate of $10 \mathrm{~Hz}$ the spike train transmits $\sim 200 \mathrm{bits} / \mathrm{s}$ whereas the stereotyped impulses transmit only $\sim 50$ bits/s [Polavieja et al., 2005]. Since the remaining $150 \mathrm{bits} / \mathrm{sec}$ are encoded in the action potential waveform, then at a firing rate of $10 \mathrm{~Hz}$ the average number of bits ${ }^{\dagger}$ encoded on each action potential waveform is estimated as $\sim 15$ bits/spike.

\subsection{Information content of spike train pattern}

The average quantity of information encoded in each spike comprising a spike train temporal pattern (not considering the information contained in an action potential waveform; Section 2.2) is variously estimated to lie between 0.01-10 bits/spike, a rather wide range.

More specifically, the information transmitted by cells in the retina and inferior temporal cortex in response to constant stimuli is estimated to be on the order of $\sim 0.01$ bits/spike [Buracas and Albright, 1999]. Neurons in monkey cortex are estimated to carry $<0.1 \mathrm{bits} /$ spike [Buracas and Albright, 1999], whereas the average neocortical spike carries about 0.01-0.2 bits/spike with some neocortical neuron spikes carrying 0.5-2 bits/spike [Buracas and Albright, 1999]. Individual neuronal spikes in spike trains from some sensory systems convey in the range of 1-3 bits/spike of information about the stimulus that triggered them [Buracas and Albright, 1999] and similar estimates of 1-3 bits/spike are reported for a wide variety of systems [Buracas and Albright, 1999]. Estimates using information-theoretic analysis of monkey visual system neurons yield information transmit rates of $\sim 1.5$ bits/spike during a spike train [Borst and Theunissen, 1999] with the general average information per spike estimated at 2-3 bits/spike [Rieke et al., 1997]. Studies of target-selective descending neuron spikes of the dragonfly report $\sim 4$ bits/spike [Adelman et al., 2003] and 1.5 bits/spike [Adelman et al., 2003], and another study [Rieke et al., 1997] finds that sensory spikes can carry between 1-10

\footnotetext{
$\dagger$ "Information" can be defined as: facts, data, or instructions in any medium or form. Mathematically, "information" is defined as a numerical measure of the uncertainty of an experimental outcome. Information is usually measured in binary digits or "bits". A bit is defined as a fundamental unit of information having two possible values, 0 or 1 . A bit can also be defined as a measure of the reduction of uncertainty, with one bit corresponding to a reduction of uncertainty by a factor of two.
} 
bits/spike of information. The quantity of entropy ${ }^{\ddagger}$ encoded in each spike of a spike train (considering only the spike train temporal pattern) is reported to vary with the firing rates, from 8 bits/spike for $\sim 3 \mathrm{~Hz}$ firing rates down to $\sim 3$ bits/spike for $\sim 100 \mathrm{~Hz}$ firing rates (Fig. 1) [Zador, 1998]. Fig. 2 shows the quantity of information, entropy, and conditional entropy ${ }^{\S}$ processed per second as a function of firing rate [Zador, 1998].

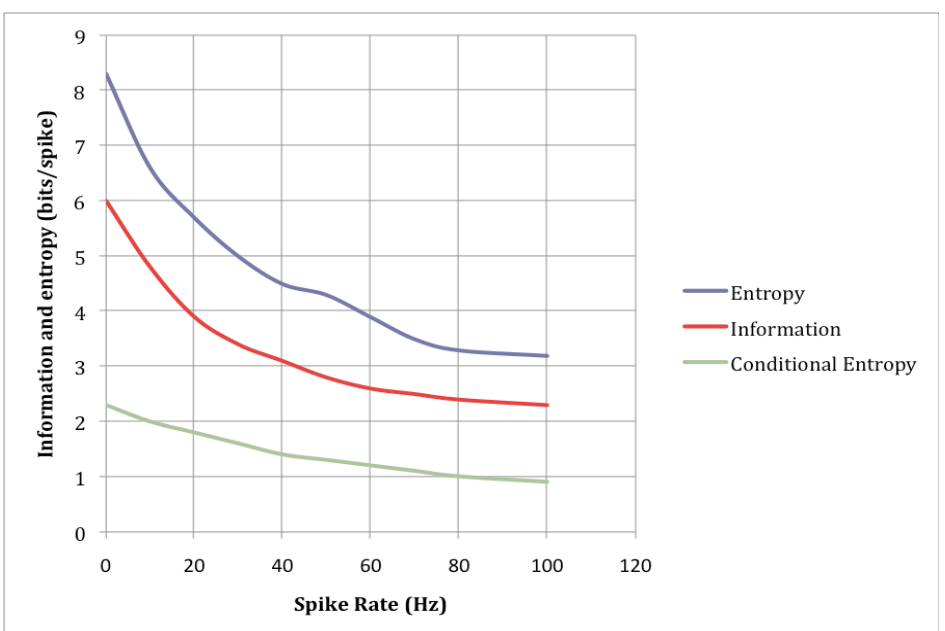

Fig 1. Quantity of average information transmitted by each spike of a spike train (considering only spike train temporal pattern) as a function of firing rate (adapted from [Zador, 1998]).

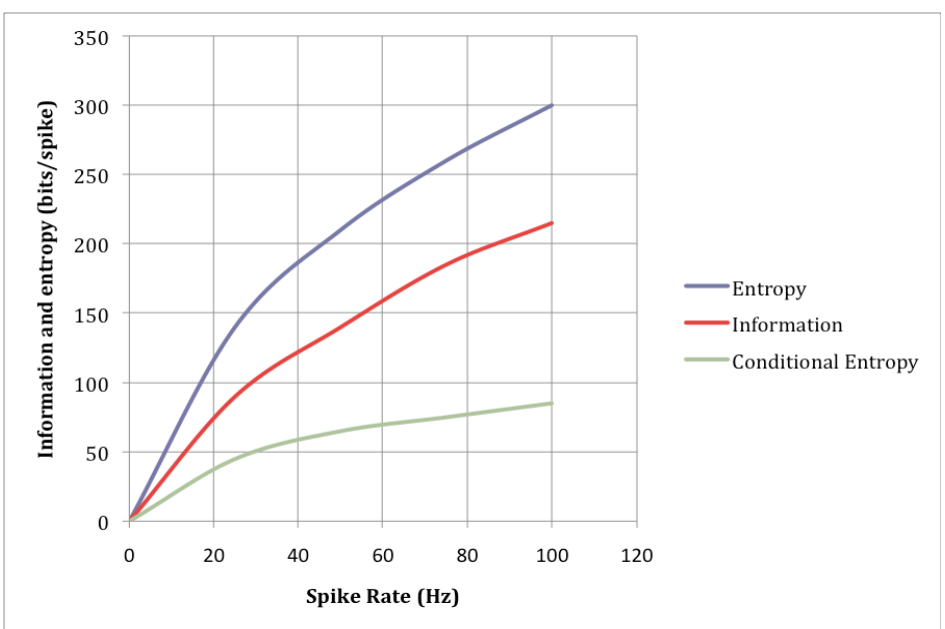

Fig 2. Quantity of average information transmitted in a spike train temporal pattern as a function of firing rate (adapted from [Zador, 1998]).

\footnotetext{
* In this context, entropy (or Shannon entropy) quantifies the total output variability of a spike train.

$\S$ Conditional entropy quantifies the variability that remains when the input signal is held constant. Information (or mutual information) quantifies the difference between entropy and conditional entropy.
} 
Summing the information carried in the spike train temporal pattern and the information encoded in each individual spike waveform, the average quantity of information transmitted per spike in neuro-electrical communication depends on the neuron average firing rate (Section 3) and is 3-4 times larger than the information transmitted in a spike train temporal pattern, thus varies between about $6-24$ bits/spike.

\section{Estimating Spike Rate using an Electrophysiological Approach}

Neural spikes are produced in neurons at the axon hillock-initial segment [Eccles, 1957] [Colbert and Johnston, 1996] [Stuart and Sakmann, 1994]. Different types of neurons have different minimum, maximum, and average spike firing rates. Neurons can be catalogued using a wide variety of characteristics such as neuron location, morphology of neuron dendritic somatic or axonic processes, neuron receptive field characteristics, axon conduction velocity, neurotransmitter content and receptors, intrinsic electrophysiological properties, and many other morphological or physiological characteristics. An estimate of the number of spikes generated in a whole human brain could be produced if neurons can be catalogued into groups having characteristic firing rates.

The first classification strategy for neurons focused on morphological characteristics. Some have argued that neuron morphological types don't have characteristic firing rates [Markram, 1998], and in fact most morphological types seem to have a very broad range of firing rates and patterns [Markram, 1998]. The inability to discriminate electrophysiological neuron types in different morphological categories was reported for rat cortical regions [Hamam et al., 2000] [Weiss and Veh, 2011] [Hamam et al., 2002] [McGann et al., 2001] [Staiger et al., 2004], rat amygdala [Faulkner and Brown, 1999], and the rat dorsal nucleus of the lateral lemniscus [Wu and Kelly, 1995]. On the other hand, although there is not a mutual correspondence between neuron morphological categories and neuron firing rates, it is also known that structural factors influence neuron electrophysiological features. For example, neurons with the same channel densities and anatomical size can have functional differentiation caused by distinctions in dendritic topology [Duijnhouwer et al., 2001]. Also, the morphology of dendrites may affect pyramidal neuron cell physiology such as electrotonic properties, action potential backpropagation, firing patterns, synaptic integration, and coincidence detection [Scorcioni et al., 2004] [Zachary, 1996]. There is a large number of morphological dendritic parameters that are used to characterize dendritic morphology and that can have some degree of impact on neuron electrophysiological features. Several studies confirm a correlation between morphological characteristics and some physiological properties [Connors et al., 1982] [Hestrin \& Armstrong, 1996] [Cauli et al., 1997] [Nambu \& Llinas, 1997] [Takakusaki et al., 1997] [Allers and Sharp, 2003] [Kuwana et al., 2006] [Lee et al., 2007] but to the best of our knowledge no current study presents the typical firing rates for each morphological type of neuron.

Apart from morphological classification, neurons can also be catalogued directly according to firing pattern, giving origin to different electrophysiological classes of neurons (16 different classes and subclasses). The different electrophysiological types of neurons seem to have characteristic average, minimum, and maximum firing rates [Diego, 2004], with different human brain regions possessing different percentages of each neuron electrophysiological type. This suggests that a useful strategy for estimating the whole-brain spike rate may be to quantify the number of neurons of each electrophysiological type. Neuron electrophysiological characteristics are very likely grounded in morphological features but to the best of our knowledge there is currently no 
study revealing the exact structural correlates of the various electrophysiological classes. In this work we consider the three main electrophysiological types of neurons in the human brain: Regular Spiking (RS), Fast Spiking (FS), and Bursting (B) [Diego, 2004] [Steriade, 2004]. Each of these three electrophysiological classes has several subclasses (e.g., intrinsically bursting or fast repetitive bursting, aka. chattering), but most such details are beyond the scope of this paper. There are also other electrophysiological neuron types such as late-spiking, low-threshold spiking, and single-spiking, but these are apparently few in number in the human brain and thus will be ignored in the present analysis.

Qualitatively, the three main electrophysiological types of neurons have several main differences. RS cells fire at low rates and adapt to continuous stimuli, while FS cells sustain very high firing frequencies with little or no adaptation and B cells generate clusters of spikes either singly or repetitively [Barry and Gutnickb, 1990]. RS and FS electrophysiological types reflect the intensity of the input in their firing frequency in linear proportion, whereas the frequency-intensity curve (response-stimulus) of B cells is highly non-linear [Diego, 2004].

Quantitatively, RS cells respond to a "typical" depolarizing stimulus of $0.3 \mathrm{nA}$ with initial frequencies of $100 \mathrm{~Hz}$ in the first 2 microseconds, then accommodate during the following $50 \mathrm{~ms}$ to steady frequencies of about $30 \mathrm{~Hz}$ (usually range 20-50 Hz) [Diego, 2004] [Wilson, 1999]. RS firing frequencies can rise to 200-300 Hz [Diego, 2004] with each spike lasting for $\sim 1 \mathrm{~ms}$ [Diego, 2004]. An FS cell responds to a depolarizing stimulus of $0.3 \mathrm{nA}$ with a sustained high frequency of $250-350 \mathrm{~Hz}$ (though discharges can sometimes reach the 400-800 Hz range) [Diego, 2004] [Wilson, 1999]. The duration of FS spikes is usually $0.4-0.6 \mathrm{~ms}$. A B cell responds to a depolarizing stimulus of $0.3 \mathrm{nA}$ with a repetitive burst discharge, with an intraburst frequency of $300 \mathrm{~Hz}$ (the first burst might reach $600 \mathrm{~Hz}$ ) and an interburst frequency of $40 \mathrm{~Hz}$ [Steriade, 2004]. B neuron high-frequency $(300-600 \mathrm{~Hz})$ spike bursts recur at fast rates $(30-50 \mathrm{~Hz})$ within a certain range of membrane potentials [Steriade, 2004][Wilson, 1999] [Steriade et al., 1998] [Wang, 1999]. Bursting neurons have two main subtypes (intrinsically bursting (IB) and fast-repetitive bursting (FRB)) having significant differences: During sustained depolarization, IB neurons fire a short burst of 3-5 action potentials at $200 \mathrm{~Hz}$ [Diego, 2004] which becomes repetitive usually at frequencies around 5-15 Hz [Diego, 2004]. During sustained depolarization, FRB neurons fire bursts containing 25 spikes at frequencies from $200-600 \mathrm{~Hz}$, with short spikes of $\sim 0.6 \mathrm{~ms}$ [Diego, 2004] bursts repeating regularly at $20-80 \mathrm{~Hz}$ [Diego, 2004].

Estimates of average firing rates indicate that FS neurons have the highest firing rates, followed by B and then RS cells [Diego, 2004]. Assuming appropriate stimulation, FastSpiking cells might achieve average firing rates of $45-55 \mathrm{~Hz}$, Bursting cells $25-35 \mathrm{~Hz}$, and Regular-Spiking cells 5-10 Hz [Diego, 2004], although there are reports of somewhat smaller mean values [Steriade et al., 2001].

To better understand the variability around the average firing rates of the different electrophysiological types of neurons we will quantify the average firing rates during three different mental states (wake, slow-wave sleep (SWS), and REM sleep) and the different firing rates for each electrophysiological neuron type while in the two principal neuron activation states (excited or resting).

The mean firing rates of the three main electrophysiological neuron types show significant differences during the three behavioral states [Steriade et al., 2001]. During the state of waking, neurons of electrophysiological type RS, B and FS have average 
firing rates of $9.4 \pm 1.7 \mathrm{~Hz}, 15.0 \pm 2.5 \mathrm{~Hz}$, and $23.7 \pm 6.1 \mathrm{~Hz}$, respectively [Steriade et al., 2001]. During SWS the three neuron types discharged respectively at $11.8 \pm 1.6 \mathrm{~Hz}, 7.5$ $\pm 1.9 \mathrm{~Hz}$, and $14.9 \pm 4.1 \mathrm{~Hz}$ [Steriade et al., 2001], while the three neuron types discharged respectively at $14.0 \pm 2.8 \mathrm{~Hz}, 5.4 \pm 2.4 \mathrm{~Hz}$ and $30.6 \pm 8.4$ during REM sleep [Steriade et al., 2001].

Electrophysiological neuron types can also be found in either an excited or a resting activation state. When excited the average spike rates of each electrophysiological type varies mainly with the depolarized resting membrane potential $\left(\mathrm{V}_{\mathrm{m}}\right)$ [Diego, 2004] or current intensity [Lionel et al., 2003]. Increases in the $\mathrm{V}_{\mathrm{m}}$ of the waking state changes completely the average firing rates [Diego, 2004]. There is a linear relationship between $\mathrm{V}_{\mathrm{m}}$ and neuron spike rate, with differences in slope: FS cells have the steepest slope at 9.2 $\mathrm{Hz} / \mathrm{mV}$, followed by B cells at 4-8 Hz/mV and RS cells with $\sim 1 \mathrm{~Hz} / \mathrm{mV}$ [Diego, 2004].

The spontaneous firing rates of different morphological and electrophysiological neuronal types are diverse and vary between $0-40 \mathrm{~Hz}$. Let us consider some examples of that variability. Cat neocortical neurons generate and synchronize a slow oscillation at $0.5-1 \mathrm{~Hz}$ [Steriade et al., 2001]. Histaminergic and aminergic neuron populations display a slow regular firing pattern at $1-4 \mathrm{~Hz}$ in the absence of synaptic activation [Haas, 2008]. The spontaneous firing rates of basolateral amygdala projection cells average $2.1 \pm 0.4$ $\mathrm{Hz}$ (ranging from $0-16 \mathrm{~Hz}$, with nearly $51.2 \%$ of projection cells firing $\leq 1 \mathrm{~Hz}$ and with an important subset firing at higher rates, up to $6.8 \mathrm{~Hz}$ ). Neurons with unusually high spontaneous firing rates of 9-16 Hz are also observed [Likhtik et al., 2006]. Spontaneous discharge of pallidal neurons is reported in the 3-19 Hz range [Raz et al., 2000] [Wilson, 1981]. In human brains, fast oscillations are reported at 30-40 Hz while awake and at REM sleep but at 1-4 Hz in SWS [Steriade et al., 1998][Llinas and Ribary, 1993].

In the resting state, different electrophysiological neuron types have different average spontaneous firing rates. RS neurons have an estimated average resting firing rate of $5 \pm$ 5.5 spikes/sec [Wilson et al., 1994]. FS neurons have reported average firing rates between $16.1 \pm 3.4 \mathrm{spikes} / \mathrm{sec}$ [Plenz and Kitai, 1998] and $17 \pm 10.8 \mathrm{spikes} / \mathrm{sec}$ [Wilson et al., 1994]. B neurons display spontaneously generated bursts of three to six action potentials with an interburst frequency of $0.2-4 \mathrm{~Hz}$; spontaneously generated bursts of 2$10 \mathrm{~Hz}$ were observed just prior to the switch to the tonic-firing mode [Wang and McCormick , 1993].

\section{Electrophysiological-Based Estimate of Whole-Brain Electrical Data Rate}

The human brain is estimated to have $(86.06 \pm 8.2) \times 10^{9}$ neurons, with $80.2 \%$ or $(69.03$ $\pm 6.65) \times 10^{9}$ neurons located in the cerebellum and $19 \%$ of those neurons or $(16.34 \pm$ $2.17) \times 10^{9}$ neurons located in the cerebral cortex, with only $0.8 \%$ or $(0.69 \pm 0.12) \times 10^{9}$ neurons in the rest of the brain [Azevedo at al., 2009]. The human cerebellum and cerebral cortex together hold the vast majority (99.2\%) of the number of neurons of the whole human brain [Azevedo at al., 2009]. The synaptic information processing rate for the brain may be estimated as: 


$$
T_{s s}(\text { spikes } / \mathrm{sec})=\sum_{i}\left[\frac{\left(F_{r s} \times R S_{i}\right)+\left(F_{b} \times B_{i}\right)+\left(F_{f s} \times F S_{i}\right)}{n_{i}}\right] \times s_{i} \quad(\text { Eqn. } 1)^{* *}
$$

and as:

$T_{s b}($ bits $/ \mathrm{sec})=3.5 \times \sum_{i}\left[\frac{\left.\left.\left.f\left(F_{r s}\right) \times F_{r s} \times R S_{i}\right)+f\left(F_{b}\right) \times F_{b} \times B_{i}\right)+f\left(F_{f s}\right) \times F_{f s} \times F S_{i}\right)}{n_{i}}\right] \times s_{i}\left(\right.$ Eqn. 2) ${ }^{* *}$

where: $T_{\mathrm{ss}}=$ whole-brain number of synaptic processed spikes per second; $\mathrm{F}_{\mathrm{rs}}=$ average firing rate of RS neurons; $\mathrm{RS}_{\mathrm{i}}=$ number of RS neurons of brain region " $i$ "; $\mathrm{F}_{\mathrm{b}}=$ average firing rate of $\mathrm{B}$ neurons; $\mathrm{B}_{\mathrm{i}}=$ number of $\mathrm{B}$ neurons of brain region " $i$ "; $\mathrm{F}_{\mathrm{fs}}=$ average firing rate of FS neurons; $\mathrm{FS}_{\mathrm{i}}=$ number of FS neurons of brain region " $i$ "; $n_{i}=$ total number of neurons in brain region " $i$ "; $s_{i}=$ total number of synapses in brain region " $i$ "; $f$ represents the function of information (Fig. 2); and $\mathrm{T}_{\mathrm{sb}}=$ whole-brain number of synaptic processed bits per second.

Experimental quantitative data on the number of neurons and the number of synapses within each main region of the human brain, along with the percentages of electrophysiological neuron types in each of those brain regions, are compiled in Table 2. Some of this data is incomplete and must be crudely estimated, pointing to the need for additional experimental efforts, but the error in the final total should be relatively small because the most populous neural subregions are comparatively well-studied - the single largest likely source of remaining error appears to be in our estimate of the number of synapses in the human cerebellum. These data may be combined using Eqns. (1) and (2) to yield an estimate of the synaptic-processed spike rate of $\mathrm{T}_{\mathrm{ss}}=(4.31 \pm 0.86) \times 10^{15}$ spikes/sec and the synaptic-processed bit rate of $\mathrm{T}_{\mathrm{sb}}=(5.52 \pm 1.13) \times 10^{16} \mathrm{bits} / \mathrm{sec}$ for the entire human brain.

Table 2. Electrical Data Processing in the Human Brain.

\begin{tabular}{|c|c|c|c|c|c|c|c|}
\hline $\begin{array}{c}\text { Region / } \\
\text { Subregion (level } \\
1 \text { ) }\end{array}$ & $\begin{array}{l}\text { Subregion } \\
\text { (level 2) }\end{array}$ & $\begin{array}{l}\text { Number of } \\
\text { Neurons }\end{array}$ & $\begin{array}{c}\text { Percentages } \\
\text { of RS } \\
\text { Neurons }\end{array}$ & $\begin{array}{c}\text { Percentages } \\
\text { of B } \\
\text { Neurons }\end{array}$ & $\begin{array}{l}\text { Percentages } \\
\text { of FS } \\
\text { Neurons }\end{array}$ & $\begin{array}{c}\text { Total } \\
\text { Number } \\
\text { of } \\
\text { Synapses }\end{array}$ & $\begin{array}{c}\text { Total } \\
\text { Electrically } \\
\text { Processed } \\
\text { Spikes/sec } \\
\text { and } \\
\text { Bits/sec } \\
\end{array}$ \\
\hline \multicolumn{8}{|l|}{ Forebrain } \\
\hline \multicolumn{8}{|l|}{$\begin{array}{c}\text { Forebrain / } \\
\text { Telencephalon }\end{array}$} \\
\hline & Cerebral Cortex & $\begin{array}{c}(2.09 \pm 0.42) \\
\times 10^{10} \\
(10)(3)\end{array}$ & $\begin{array}{c}54 \% \\
\text { [Steriade et } \\
\text { al., } 1998] \\
\text { (1) }\end{array}$ & $\begin{array}{c}43 \% \\
\text { [Steriade et } \\
\text { al., 1998] } \\
\text { (2) }\end{array}$ & $\begin{array}{c}3 \% \\
\text { [Steriade et } \\
\text { al., } 1998] \\
\text { (4) }\end{array}$ & $\begin{array}{c}(1.64 \pm \\
0.26) \mathrm{x} \\
10^{14} \\
{[\text { Tang et }} \\
\text { al. 2001, } \\
2003]\end{array}$ & $\begin{array}{c}(3.03 \pm \\
0.48) \times 10^{15} \\
\text { spikes/sec, } \\
(3.92 \pm \\
0.63) \times 10^{16} \\
\text { bits/sec }\end{array}$ \\
\hline
\end{tabular}

\footnotetext{
** Even distribution of synapses among the different electrophysiological types of neurons is assumed in Eqns. 1 and 2 .
} 
(6) (20)

\begin{tabular}{|c|c|c|c|c|c|c|}
\hline $\begin{array}{l}\text { Cerebral Cortex } \\
\text { / Frontal Lobe }\end{array}$ & $\begin{array}{c}(6.70 \pm 1.41) \\
\quad x 10^{9} \\
\text { [Pedersen, } \\
2005] \\
(11)\end{array}$ & $\begin{array}{c}95 \% \\
\text { [Chang and } \\
\text { Luebke, } \\
\text { 2007] }\end{array}$ & $\begin{array}{c}5 \% \\
\text { [Chang and } \\
\text { Luebke, } \\
\text { 2007] }\end{array}$ & $\begin{array}{c}0 \% \\
\text { [Chang and } \\
\text { Luebke, } \\
\text { 2007] }\end{array}$ & $\begin{array}{c}(5.85 \pm \\
1.34) \mathrm{x} \\
10^{13} \\
{[\text { Tang et }} \\
\text { al. } 2001 \text {, } \\
2003] \\
(20) \\
\end{array}$ & $\begin{array}{c}(5.05 \pm \\
1.16) \times 10^{14} \\
\text { spikes/sec, } \\
(8.34 \pm \\
1.91) \times 10^{15} \\
\text { bits/sec }\end{array}$ \\
\hline $\begin{array}{c}\text { Cerebral Cortex } \\
\text { / Insula }\end{array}$ & $\begin{array}{c}(8.72 \pm 0.33) \\
\text { x } 10^{8} \\
\text { (est.) } \\
(8)\end{array}$ & $\begin{array}{c}54 \% \\
\text { [Steriade et } \\
\text { al., 1998] } \\
(1)(21)\end{array}$ & $\begin{array}{c}43 \% \\
\text { [Steriade } e t \\
\text { al. }, 1998] \\
(2)(21)\end{array}$ & $\begin{array}{c}3 \% \\
\text { [Steriade et } \\
\text { al. }, 1998] \\
\text { (4) (21) }\end{array}$ & $\begin{array}{c}(6.05 \pm \\
0.23) \mathrm{x} \\
10^{12} \\
(\text { est. }) \\
(8)\end{array}$ & $\begin{array}{c}(1.12 \pm \\
0.04) \times 10^{14} \\
\text { spikes/sec, } \\
(1.45 \pm \\
0.05) \times 10^{15} \\
\text { bits/sec }\end{array}$ \\
\hline $\begin{array}{l}\text { Cerebral Cortex } \\
\text { / Limbic Lobe }\end{array}$ & $\begin{array}{c}(1.39 \pm 0.30) \\
\times 10^{9} \\
(9)\end{array}$ & $\begin{array}{c}82 \% \\
\text { [Tavares, } \\
2006]\end{array}$ & $\begin{array}{c}16 \% \\
\text { [Tavares, } \\
2006]\end{array}$ & $\begin{array}{c}2 \% \\
{[\text { Tavares, }} \\
2006]\end{array}$ & $\begin{array}{c}(4.00 \pm \\
1.05) \mathrm{x} \\
10^{13} \\
\text { synapses } \\
\text { (est.) } \\
(9) \\
\end{array}$ & $\begin{array}{c}(4.78 \pm \\
1.25) \times 10^{14} \\
\text { spikes/sec, } \\
(6.98 \pm \\
1.83) \times 10^{15} \\
\text { bits } / \mathrm{sec}\end{array}$ \\
\hline $\begin{array}{l}\text { Cerebral Cortex } \\
\text { / Occipital Lobe }\end{array}$ & $\begin{array}{c}(4.10 \pm 0.99) \\
\text { x } 10^{9} \\
\text { [Pedersen, } \\
2005] \\
(12)\end{array}$ & $\begin{array}{c}54 \% \\
\text { [Steriade et } \\
\text { al., 1998] } \\
(1)(21)\end{array}$ & $\begin{array}{c}43 \% \\
\text { [Steriade } \text { et } \\
\text { al. }, 1998] \\
(2)(21)\end{array}$ & $\begin{array}{c}3 \% \\
\text { [Steriade } e t \\
\text { al. }, 1998] \\
\text { (4) (21) }\end{array}$ & $\begin{array}{c}2.20 \pm \\
1.83 \mathrm{x} \\
10^{13} \\
{[\text { Tang et }} \\
\text { al. } 2001, \\
2003] \\
(20) \\
\end{array}$ & $\begin{array}{c}(4.06 \pm \\
3.38) \times 10^{14} \\
\text { spikes/sec, } \\
(5.26 \pm \\
4.38) \times 10^{15} \\
\text { bits/sec }\end{array}$ \\
\hline $\begin{array}{l}\text { Cerebral Cortex } \\
\text { / Parietal Lobe }\end{array}$ & $\begin{array}{c}(4.20 \pm 0.92) \\
\text { x } 10^{9} \\
\text { [Pedersen, } \\
2005] \\
(13)\end{array}$ & $\begin{array}{c}54 \% \\
\text { [Steriade et } \\
\text { al., 1998] } \\
(1)(21)\end{array}$ & $\begin{array}{c}43 \% \\
\text { [Steriade } \text { et } \\
\text { al. }, 1998] \\
(2)(21)\end{array}$ & $\begin{array}{c}3 \% \\
\text { [Steriade } e t \\
a l ., 1998] \\
\text { (4) }(21)\end{array}$ & $\begin{array}{c}(4.15 \pm \\
0.568) \mathrm{x} \\
10^{13} \\
{[\text { Tang et }} \\
\text { al. } 2001 \text {, } \\
2003] \\
(20) \\
\end{array}$ & $\begin{array}{c}(7.66 \pm \\
1.04) \times 10^{14} \\
\text { spikes/sec, } \\
(9.92 \pm \\
1.36) \times 10^{15} \\
\text { bits/sec }\end{array}$ \\
\hline $\begin{array}{c}\text { Cerebral Cortex } \\
\text { / Temporal } \\
\text { Lobe }\end{array}$ & $\begin{array}{c}(3.60 \pm 0.50) \\
\text { x } 10^{9} \\
\text { [Pedersen, } \\
2005] \\
(14)\end{array}$ & $\begin{array}{c}61 \% \\
\text { [Avoli, } \\
1994] \\
(24)\end{array}$ & $\begin{array}{c}36 \% \\
\text { [Avoli, } \\
1994] \\
(24)\end{array}$ & $\begin{array}{c}3 \% \\
\text { [Steriade } e t \\
\text { al. }, 1998] \\
\text { (4) }(21)\end{array}$ & $\begin{array}{c}(4.20 \pm \\
1.35) \mathrm{x} \\
10^{13} \\
{[\text { Tang et }} \\
\text { al. } 2001 \text {, } \\
2003] \\
(20)\end{array}$ & $\begin{array}{c}(7.09 \pm \\
2.28) \times 10^{14} \\
\text { spikes/sec, } \\
(9.38 \pm \\
3.01) \times 10^{15} \\
\text { bits/sec }\end{array}$ \\
\hline
\end{tabular}


Cerebral Nuclei

\begin{tabular}{|c|c|c|c|c|c|c|c|}
\hline & $\begin{array}{l}\text { Cerebral Nuclei } \\
\text { / Amygdala }\end{array}$ & $\begin{array}{c}(1.22 \pm 0.13) \\
\text { x } 10^{7} \\
\text { [Schumann } \\
\text { and Amaral, } \\
2005] \\
(15) \\
\end{array}$ & $\begin{array}{c}92 \% \\
{[\text { Faber et }} \\
\text { al., 2001] }\end{array}$ & $\begin{array}{c}1 \% \\
{[\text { Faber et }} \\
\text { al., 2001] }\end{array}$ & $\begin{array}{c}7 \% \\
\text { [Faber et } \\
\text { al., 2001] }\end{array}$ & $\begin{array}{c}(8.47 \pm \\
0.90) \mathrm{x} \\
10^{10} \\
\text { (est.) } \\
(22)\end{array}$ & $\begin{array}{c}(9.06 \pm \\
0.96) \times 10^{12} \\
\text { spikes/sec, } \\
(1.34 \pm \\
0.14) \times 10^{13} \\
\text { bits/sec }\end{array}$ \\
\hline & $\begin{array}{c}\text { Cerebral Nuclei } \\
\text { / Anterior } \\
\text { Olfactory } \\
\text { Nucleus }\end{array}$ & $\begin{array}{l}1.76 \times 10^{8} \\
(18)(33)\end{array}$ & $\begin{array}{c}54 \% \\
\text { [Steriade } e t \\
\text { al. }, 1998] \\
\text { (1) (21) }\end{array}$ & $\begin{array}{c}43 \% \\
\text { [Steriade } e t \\
\text { al. }, 1998] \\
(2)(21)\end{array}$ & $\begin{array}{c}3 \% \\
\text { [Steriade } e t \\
\text { al. }, 1998] \\
\text { (4) (21) }\end{array}$ & $\begin{array}{c}(1.22 \pm \\
0.20) \mathrm{x} \\
10^{12} \\
(33)\end{array}$ & $\begin{array}{c}(2.25 \pm \\
0.37) \times 10^{13} \\
\text { spikes/sec, } \\
(2.91 \pm \\
0.48) \times 10^{14} \\
\text { bits/sec }\end{array}$ \\
\hline & $\begin{array}{c}\text { Cerebral Nuclei } \\
\text { / Basal } \\
\text { Forebrain }\end{array}$ & $\begin{array}{c}1.58 \times 10^{9} \\
(33)\end{array}$ & $\begin{array}{c}52 \% \\
{[\text { Pang et }} \\
a l ., 1998] \\
\text { (est.) }\end{array}$ & $\begin{array}{c}20 \% \\
\text { [Pang et } \\
\text { al., 1998] } \\
\text { (est.) }\end{array}$ & $\begin{array}{c}28 \% \\
\text { [Pang et } \\
\text { al., 1998] } \\
\text { (est.) }\end{array}$ & $\begin{array}{c}(1.10 \pm \\
0.18) \mathrm{x} \\
10^{13} \\
(33)\end{array}$ & $\begin{array}{c}(2.63 \pm \\
0.43) \times 10^{14} \\
\text { spikes/sec, } \\
(3.05 \pm \\
0.50) \times 10^{15} \\
\text { bits } / \mathrm{sec}\end{array}$ \\
\hline & $\begin{array}{l}\text { Cerebral Nuclei } \\
\text { / Basal Ganglia }\end{array}$ & $\begin{array}{c}(4.15 \pm 0.99) \\
\text { x } 10^{8} \\
\text { [Karlsen and } \\
\text { Pakkenberg, } \\
\text { 2011] }\end{array}$ & $\begin{array}{c}54 \% \\
\text { [Steriade et } \\
\text { al. }, 1998] \\
(1)(21)\end{array}$ & $\begin{array}{c}43 \% \\
\text { [Steriade et } \\
\text { al. }, 1998] \\
(2)(21)\end{array}$ & $\begin{array}{c}3 \% \\
\text { [Steriade et } \\
\text { al. }, 1998] \\
\text { (4) }(21)\end{array}$ & $\begin{array}{c}(2.88 \pm \\
0.69) \mathrm{x} \\
10^{12} \\
(31)\end{array}$ & $\begin{array}{c}(5.31 \pm \\
1.27) \times 10^{13} \\
\text { spikes/sec, } \\
(6.89 \pm \\
1.65) \times 10^{14} \\
\text { bits/sec }\end{array}$ \\
\hline & $\begin{array}{c}\text { Cerebral Nuclei } \\
\text { / Claustrum }\end{array}$ & $\begin{array}{c}6.50 \times 10^{7} \\
(32)\end{array}$ & $\begin{array}{c}54 \% \\
\text { [Steriade } e t \\
\text { al., 1998] } \\
\text { (1) (21) }\end{array}$ & $\begin{array}{c}43 \% \\
\text { [Steriade } e t \\
\text { al. }, 1998] \\
(2)(21)\end{array}$ & $\begin{array}{c}3 \% \\
\text { [Steriade et } \\
\text { al. }, 1998] \\
\text { (4) (21) }\end{array}$ & $\begin{array}{c}(4.51 \pm \\
0.72) \mathrm{x} \\
10^{11} \\
(32)\end{array}$ & $\begin{array}{c}(8.32 \pm \\
1.33) \times 10^{12} \\
\text { spikes/sec, } \\
(1.08 \pm \\
0.17) \times 10^{14} \\
\text { bits/sec }\end{array}$ \\
\hline \multicolumn{8}{|l|}{$\begin{array}{c}\text { Forebrain / } \\
\text { Diencephalon }\end{array}$} \\
\hline & Thalamus & $\begin{array}{c}7.88 \times 10^{6} \\
\text { [Kreczmanski, } \\
2007] \\
(16)\end{array}$ & $\begin{array}{c}38.8 \% \\
(21)\end{array}$ & $\begin{array}{c}30.9 \% \\
(21)\end{array}$ & $\begin{array}{c}28 \% \\
\text { [Steriade et } \\
\text { al. }, 1998]\end{array}$ & $\begin{array}{c}(5.47 \pm \\
0.87) \mathrm{x} \\
10^{10} \\
\text { (est.) } \\
(16)\end{array}$ & $\begin{array}{c}(1.43 \pm \\
0.23) \times 10^{12} \\
\text { spikes/sec, } \\
(1.63 \pm \\
0.26) \times 10^{13} \\
\text { bits } / \mathrm{sec}\end{array}$ \\
\hline & Hypothalamus & $\begin{array}{c}(2.02 \pm 0.47) \\
\times 10^{8}\end{array}$ & $\begin{array}{l}66 \% \\
\text { (est.) }\end{array}$ & $\begin{array}{c}30 \% \\
\text { [Tasker and }\end{array}$ & $\begin{array}{l}4 \% \\
\text { (est.) }\end{array}$ & $\begin{array}{l}(4.42 \pm \\
0.24) \mathrm{x}\end{array}$ & $\begin{array}{c}(6.85 \pm \\
0.37) \times 10^{13}\end{array}$ \\
\hline
\end{tabular}


(est.) Dudek, $\quad 10^{12} \quad$ spikes/sec,

1991] (27) (est.) $\quad(9.08 \pm$

(25) (27) 0.49$) \times 10^{14}$ bits/sec

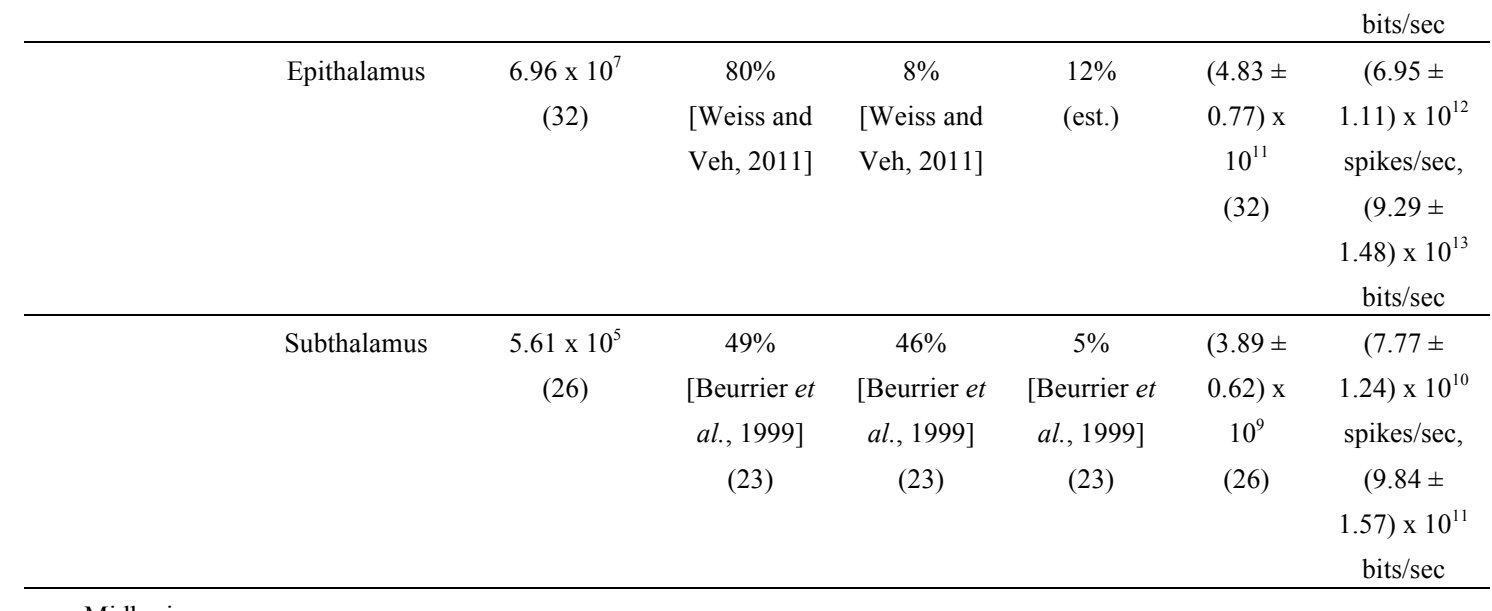

Midbrain

Midbrain /

Mesencephalon

$\begin{array}{ccccccc}\text { Midbrain } & 1.54 \times 10^{8} & 54 \% & 43 \% & 3 \% & (1.07 \pm & (1.97 \pm \\ \text { Tectum } & \text { (est.) } & \text { [Steriade } \text { et } & \text { [Steriade } \text { et } & \text { [Steriade } \text { et } & 0.17) \times & 0.31) \times 10^{13} \\ & (29) & \text { al., 1998] } & \text { al., 1998] } & \text { al., 1998] } & 10^{12} & \text { spikes } / \mathrm{sec},\end{array}$

$\begin{array}{llll}(1)(21) & \text { (2) }(21) & \text { (4) }(21) & \text { (est.) }\end{array}$

(29) 0.40$) \times 10^{14}$

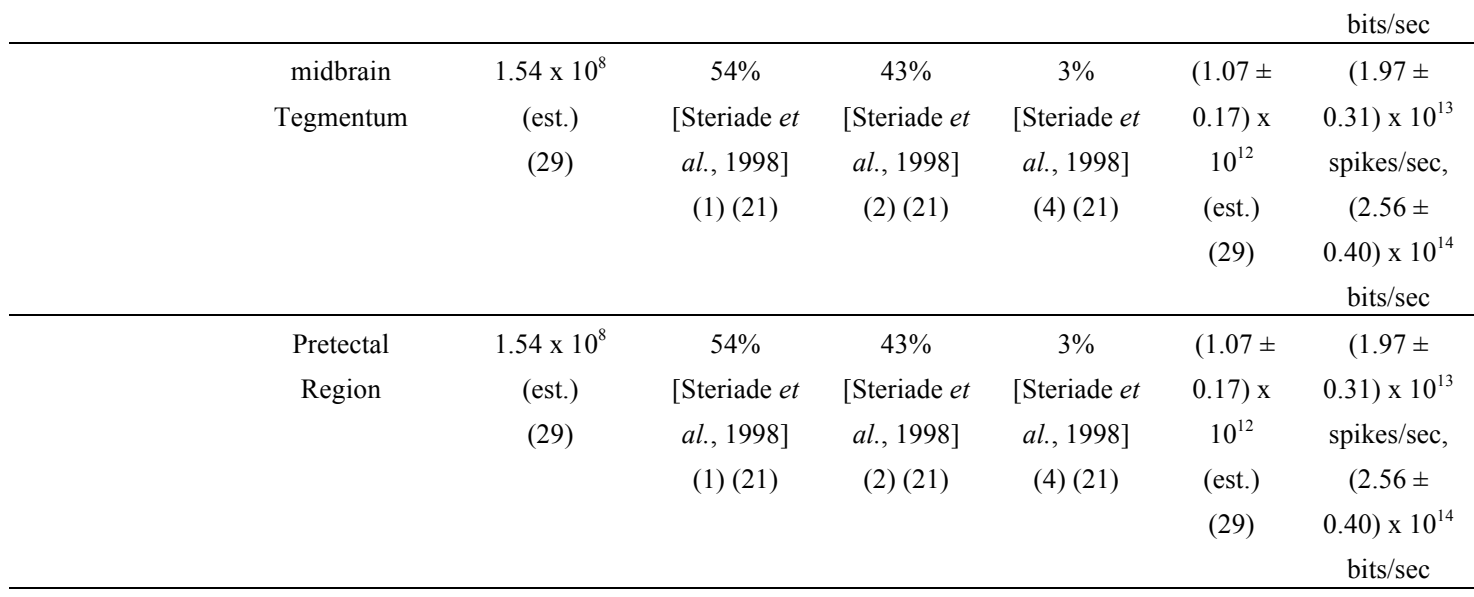

Hindbrain

Hindbrain /

Metencephalon 
Nuno R. B. Martins, Wolfram Erlhagen, Robert A. Freitas Jr.

\begin{tabular}{|c|c|c|c|c|c|c|c|}
\hline & Pons & $\begin{array}{c}(9.63 \pm 2.12) \\
\mathrm{x} 10^{8} \\
(\text { est. }) \\
(30)\end{array}$ & $\begin{array}{c}54 \% \\
\text { [Steriade et } \\
\text { al., 1998] } \\
(1)(21)\end{array}$ & $\begin{array}{c}43 \% \\
\text { [Steriade } e t \\
\text { al. }, 1998] \\
\text { (2) (21) }\end{array}$ & $\begin{array}{c}3 \% \\
\text { [Steriade et } \\
\text { al., 1998] } \\
(4)(21)\end{array}$ & $\begin{array}{c}(6.68 \pm \\
1.06) \mathrm{x} \\
10^{12} \\
(30)\end{array}$ & $\begin{array}{c}(1.23 \pm \\
0.20) \times 10^{14} \\
\text { spikes/sec, } \\
(1.60 \pm \\
0.25) \times 10^{15} \\
\text { bits/sec }\end{array}$ \\
\hline & Cerebellum & $\begin{array}{c}(6.903 \pm \\
0.665) \times 10^{10} \\
\text { [Azevedo et } \\
\text { al., 2009] } \\
(17)\end{array}$ & $\begin{array}{c}54 \% \\
\text { [Steriade } e t \\
\text { al. }, 1998] \\
(1)(21)\end{array}$ & $\begin{array}{c}43 \% \\
\text { [Steriade } e t \\
\text { al. }, 1998] \\
\text { (2) (21) }\end{array}$ & $\begin{array}{c}3 \% \\
\text { [Steriade et } \\
\text { al., 1998] } \\
(4)(21)\end{array}$ & $\begin{array}{c}3.35 \pm \\
1.54 \mathrm{x} \\
10^{13}(19)\end{array}$ & $\begin{array}{c}(6.28 \pm \\
2.84) \mathrm{x} \\
10^{14} \\
\text { spikes/sec, } \\
(8.01 \pm \\
3.68) \mathrm{x} \\
10^{15} \\
\text { bits/sec }\end{array}$ \\
\hline \multicolumn{8}{|l|}{$\begin{array}{c}\text { Hindbrain / } \\
\text { Myelencephalon }\end{array}$} \\
\hline & $\begin{array}{c}\text { Medulla } \\
\text { Oblongata }\end{array}$ & $\begin{array}{c}(2.87 \pm 0.63) \\
10^{8} \\
(\text { est. }) \\
(28)\end{array}$ & $\begin{array}{c}54 \% \\
\text { [Steriade et } \\
\text { al., 1998] } \\
\text { (1) (21) }\end{array}$ & $\begin{array}{c}43 \% \\
\text { [Steriade } e t \\
\text { al. }, 1998] \\
\text { (2) (21) }\end{array}$ & $\begin{array}{c}3 \% \\
\text { [Steriade et } \\
\text { al., 1998] } \\
\text { (4) (21) }\end{array}$ & $\begin{array}{c}(1.99 \pm \\
0.32) \mathrm{x} \\
10^{12} \\
(\text { est. }) \\
(28)\end{array}$ & $\begin{array}{c}(3.67 \pm \\
0.59) \times 10^{13} \\
\text { spikes/sec, } \\
(4.76 \pm \\
0.76) \times 10^{14} \\
\text { bits/sec }\end{array}$ \\
\hline Total & Total & $\begin{array}{c}(9.42 \pm 1.13) \\
\times 10^{10}\end{array}$ & $\begin{array}{l}54 \% \\
\text { (est.) }\end{array}$ & $\begin{array}{l}43 \% \\
\text { (est.) }\end{array}$ & $\begin{array}{l}3 \% \\
\text { (est.) }\end{array}$ & $\begin{array}{c}(2.42 \pm \\
0.29) \mathrm{x} \\
10^{14}\end{array}$ & $\begin{array}{c}(4.31 \pm \\
0.86) \times 10^{15} \\
\text { spikes/sec, } \\
(5.52 \pm \\
1.13) \times 10^{16} \\
\text { bits/sec }\end{array}$ \\
\hline
\end{tabular}

Notes:

1. Reported range is 51\%-73\% [Steriade et al., 1998, 2001] [Foehring, 1990] [Franceschetti, et al., 1995].

2. The $43 \%$ is divided as $28 \%$ FRB and $15 \%$ IB [Steriade et al., 1998]. The total percentage of bursting neurons ranges from: 4\%-43\% [Steriade et al., 1998, 2001].

3. Estimates of the number of neocortical neurons include: $17.8 \times 10^{9}$ [Karlsen and Pakkenberg, 2011], $20.5 \mathrm{x}$ $10^{9}(\mathrm{CV}=0.13)$ [Bundgaard, 2001], $21.2 \times 10^{9}$ [Pelvig et al., 2003], $22.06 \times 10^{9}$ [Pakkenberg, 1993], $23 \mathrm{x}$ $10^{9}$ [Pakkenberg and Gundersen, 1997] [Schumann and Amaral, 2005], $24.4 \times 10^{9}$ [Fischer, 1999] and 28 x $10^{9}$ neurons [Wilson, 1999]. The total number of neocortical neurons in the right hemisphere of five normal 80-year-old men was estimated to be $13.7 \times 10^{9}$ with an inter-individual coefficient of variation of $12 \%$ [Braendgaard et al., 1990]. Gender differences are illustrated on the estimate of $22.9 \times 10^{9}$ for males and $19.7 \times 10^{9}$ for females [Scorcioni et al., 2004]. To illustrate the differences between healthy and disease states, the number of neocortex neurons was estimated as $24.4 \times 10^{9}$ in healthy individuals and $18.3 \times 10^{9}$ in AIDS patients [Fischer, 1999]. The number of neurons in the neocortex also changes with gender and 
height [Pakkenberg and Gundersen, , 1997]. The range of neocortical number of neurons is reported in the range of $14.7 \times 10^{9}$ to $32.0 \times 10^{9}$, with mean values of $19.3 \times 10^{9}$ and $22.8 \times 10^{9}$ for females and males, respectively [Pakkenberg and Gundersen, 1997].

4. Reported range is 3\%-24\% [Steriade et al., 1998, 2001].

5. Some have reported that the cerebral cortex synaptic density is between $15.08 \times 10^{8} / \mathrm{mm}^{3}$ and $16.26 \mathrm{x}$ $10^{8} / \mathrm{mm}^{3}$ [deFilipe, 1999]. The numerical density of synapses in the six layers of the human cerebral cortex is reported between $10-20 \times 10^{8} / \mathrm{mm}^{3}$ [deFilipe, 1999]. The frontal cerebral cortex numerical synaptic density was reportedly constant throughout adult human life (ages 16-72 years) with a mean of $11.05 \times 10^{8}$ synapses $/ \mathrm{mm}^{3}$ ( \pm 0.41 S.E.M), but there is a slight decline in synaptic density in the brains of humans aged 74-90 years with a mean of $9.56 \times 10^{8}$ synapses $/ \mathrm{mm}^{3}$ ( \pm 0.28 S.E.M) [Huttenlocher, 1979].

6. Others have estimated $1.5 \times 10^{14}$ [Pakkenberg, 2003].

7. $\mathrm{T}_{\mathrm{SS}}(\mathrm{spikes} / \mathrm{sec})=\left[\left(\left(7.5 \mathrm{spikes} / \mathrm{sec} \times\left(1.02 \times 10^{10}\right)\right.\right.\right.$ neurons +30 spikes $/ \mathrm{sec} \times\left(0.81 \times 10^{10}\right)$ neurons +50 spikes/sec $\times\left(0.056 \times 10^{10}\right)$ neurons $\left.) / 1.88 \times 10^{10}\right) \times\left(1.64 \times 10^{14}\right)$ synapses $]=3.03 \times 10^{15}$ spikes $/ \mathrm{sec}$. $\mathrm{T}_{\mathrm{SB}}$ $($ bits $/ \mathrm{sec})=3.5 \times\left[\left(\left(5\right.\right.\right.$ bits $\times 7.5$ spikes $/ \mathrm{sec} \times\left(1.02 \times 10^{10}\right)$ neurons +3.4 bits $\times 30$ spikes $/ \mathrm{sec} \times\left(0.81 \times 10^{10}\right)$ neurons +2.8 bits $\times 50$ spikes $/ \mathrm{sec} \times\left(0.056 \times 10^{10}\right)$ neurons $\left.) / 1.88 \times 10^{10}\right) \times\left(1.64 \times 10^{14}\right)$ synapses] $=5.712$ x $10^{16} \mathrm{bits} / \mathrm{sec}$.

8. The insula has two portions: the anterior insula (larger) and the posterior insula (smaller) [Türe et al., 1999]. The anterior insular cortex volume is: $3800 \mathrm{~mm}^{3}(\mathrm{SD}=420)$ (left) and $3550 \mathrm{~mm}^{3}(\mathrm{SD}=332)$ (right). The posterior insular cortex volume is: $1992 \mathrm{~mm}^{3}(\mathrm{SD}=245)$ (left) and $1916 \mathrm{~mm}^{3}(\mathrm{SD}=223)$ (right) [Nishida et al., 2011]. The total volume of the human insula is thus $11,258 \mathrm{~mm}^{3}$. Assuming a synaptic density of 11.05 $\mathrm{x} 10^{8} / \mathrm{mm}^{3}$ (average synaptic density reported for the neocortex [Huttenlocher, 1979]), the insula would have $1.24 \times 10^{13}$ synapses. The volume of the insula is estimated as: $17.3 \pm 1.9 \mathrm{~cm}^{3}$ [Kennedy, et al., 1998]. As the neocortex neuron density was estimated as $50.4 \times 10^{6} / \mathrm{cm}^{3} \pm 11.08 \times 10^{6}(\mathrm{CV}=0.22)$ [Bundgaard, 2001], we estimate the number of neurons of the human insula as $(8.72 \pm 0.33) \times 10^{8}$ neurons. Assuming an average of $6.94 \times 10^{3}$ synapses per neuron (as in the human cerebral cortex [Tang et al., 2003]), the insula would have $(6.05 \pm 0.23) \times 10^{12}$ synapses.

9. a) The limbic lobe is composed of the hippocampus, the parahippocampus, cingulate cortex, and the piriform cortex. The volume of hippocampus is $1.542 \pm 1.12 \mathrm{~cm}^{3}$ [Simic et al., 1997]. The volume of the parahippocampus is: $4.3 \pm 0.9 \mathrm{~cm}^{3}$ (anterior) and $4.1 \pm 1.2 \mathrm{~cm}^{3}$ (posterior), for a total of $8.4 \pm 2.1 \mathrm{~cm}^{3}$ [Kennedy, et al., 1998]; others reported $7.1 \pm 0.86 \mathrm{~cm}^{3}$ [Raz, 2004]. The volume of the male cingulate cortex is estimated as $9.32 \pm 2.39 \mathrm{~cm}^{3}$ (left hemisphere) and $8.60 \pm 2.06 \mathrm{~cm}^{3}$ (right hemisphere) [Highley et al., 2001], total volume $17.92 \pm 4.45 \mathrm{~cm}^{3}$ [Highley et al., 2001]. The volume of the piriform cortex and cortical amygdala is estimated as $530 \pm 59 \mathrm{~mm}^{3}$ (right cortex) and $512 \pm 60 \mathrm{~mm}^{3}$ (left cortex) [Pereira, et al., 2005]. Total limbic lobe volume is thus estimated as: $27.6 \mathrm{~cm}^{3}$. b) The hippocampus has five main subdivisions (granule cell layer, hilus, CA3-2, CA1, and subiculum) with the following mean numbers of neurons in each subdivision: granule cell layer $15 \times 10^{6}(0.28)$, hilus $2.0 \times 10^{6}(0.16)$, CA3-2 $2.7 \times 10^{6}(0.22)$, CA1 $16 \times 10^{6}(0.32)$, subiculum $4.5 \times 10^{6}(0.19)$ [West and Gundersen, 1990] [Schumann and Amaral, 2005], giving a total of $4.02 \times 10^{7}$ neurons. The total number of neurons in the hippocampus was also reported as $(4.85 \pm 0.84) \times 10^{7}$ [Simic et al., 1997]. The synaptic densities in the hippocampal subiculum and CA1 were reported as $(11.98 \pm 1.69) \times 10^{8} / \mathrm{mm}^{3}$ (subiculum) 
and $(14.51 \pm 3.81) \times 10^{8} / \mathrm{mm}^{3}$ (CA1) [Alonso-Nanclares et al., 2011]. The neocortex neuron density was estimated as $(50.4 \pm 11.08) \times 10^{6} / \mathrm{cm}^{3}$ with the numerical density in each of the four neocortex lobes as follows: frontal lobe $40.9 \times 10^{6} / \mathrm{cm}^{3}(0.30)$, temporal lobe $44.6 \times 10^{6} / \mathrm{cm}^{3}(0.20)$, parietal lobe $49.8 \times 10^{6} /$ $\mathrm{cm}^{3}(0.18)$, occipital lobe $93.0 \times 10^{6} / \mathrm{cm}^{3}(0.27)$ [Bundgaard, 2001].

10. The number of neurons in the cerebral cortex is estimated as $2.8 \times 10^{10}$ [Bundgaard, 2001] and (1.634 \pm 2.17) $\times 10^{10}$ [Azevedo et al., 2009]. There seems to be no estimate for the number of neurons in the neocortex smaller than $1.634 \times 10^{10}$ [Azevedo et al., 2009].

11. Others estimated $6.61 \times 10^{9}$ [Bundgaard, 2001], including $7.82 \times 10^{9}(0.25)$ (male) and $6.59 \times 10^{9}(0.24)$ (female) [Pakkenberg and Gundersen, 1997].

12. For the whole occipital lobe, others estimated $4.67 \times 10^{9}$ [Bundgaard, 2001], including $4.89 \times 10^{9}(0.22)$ (male) and $4.28 \times 10^{9}$ (0.28) (female) [Pakkenberg and Gundersen, 1997].

13. For the parietal lobe, others estimated $5.10 \times 10^{9}$ [Bundgaard, 2001], including $5.51 \times 10^{9}(0.28)$ (male) and $4.50 \times 10^{9}(0.28)$ (female) [Pakkenberg and Gundersen, 1997].

14. For the temporal lobe, others estimated $4.13 \times 10^{9}$ [Bundgaard, 2001], including $4.21 \times 10^{9}$ (0.34) (male) and $3.59 \times 10^{9}(0.31)$ (female) [Pakkenberg and Gundersen, 1997].

15. There are approximately $12.21 \times 10^{6}$ neurons in the human amygdaloid complex with more than $50 \%$ residing in the lateral and basal nuclei [Schumann and Amaral, 2005]. The mean number of neurons for each region is $4.00 \times 10^{6}$ (lateral nucleus), $3.24 \times 10^{6}$ (basal nucleus), $1.28 \times 10^{6}$ (accessory basal nucleus), $0.36 \times 10^{6}$ (central nucleus) and $3.33 \times 10^{6}$ (remaining nuclei).

16. Total neuron numbers are reported as $32.7 \times 10^{6}$ (caudate nucleus), $35.4 \times 10^{6}$ (Putamen), $2.43 \times 10^{6}$ (nucleus accumbens), $3.79 \times 10^{6}$ (mediodorsal nucleus of the thalamus), and $4.43 \times 10^{6}$ (lateral nucleus of the amygdala) [Kreczmanski, 2007]. Assuming the number of neurons is $7.875 \times 10^{6}$ [Kreczmanski, 2007] and assuming an average of $(6.94 \pm 1.11) \times 10^{3}$ synapses per neuron (as in the human cerebral cortex [Tang et al., 2003]), the thalamus would have $(5.47 \pm 0.87) \times 10^{10}$ synapses.

17. The number of neurons in the human cerebellum was estimated as $1.05 \times 10^{11}$ [Andersen et al., 1992] with between 1.01-1.09 x 10 11 granule cells and 28-30.5 x $10^{6}$ Purkinje cells [Andersen and Pakkenberg, 2003] [Andersen et al., 1992], with subsequent work refining these latter estimates to $1.087 \times 10^{11}$ granule cells and $28.6 \times 10^{6}$ Purkinje cells [Andersen, 2003]. However, the cerebellum was most recently estimated to have $0.6903 \pm 0.0665 \times 10^{11}$ neurons [Azevedo et al., 2009] which is the figure we adopt here.

18. The anterior olfactory nucleus was reported to be poorly studied in the literature [Brunjes et al., 2005].

19. There are no published studies on synapse counts in the human cerebellum because the currently available stereological methods are not well suited for synapses and would not permit counting in a reasonable time [A.S. Karlsen, private communication, 2011]. The cerebellum (of rats) was reported to have a synaptic density between $3-4 \times 10^{8} / \mathrm{mm}^{3}$ [Kleim, 2002] but others report a synaptic density (also for rats) of $2 \mathrm{x}$ $10^{8} / \mathrm{mm}^{3}$ [Black et al., 1990]. The average volume of the cerebellum has been reported from a low of 60.11 $\mathrm{cm}^{3}$ to a high of $170.6 \mathrm{~cm}^{3}$ [Kandel, 2000] [Andreasen, 1996], and as $117.75 \pm 10.7 \mathrm{~cm}^{3}$ (males) and 111.83 $\pm 8.0 \mathrm{~cm}^{3}$ (females). The human cerebellum white matter volume was estimated as $31.9 \mathrm{~cm}^{3}$ and the cortex volume as $90.8 \mathrm{~cm}^{3}$ for a total of $124.8 \mathrm{~cm}^{3}$ [Andersen et al., 2003]. Assuming a representative synaptic density of $4 \times 10^{8} / \mathrm{mm}^{3}$ and a cerebellum cortex volume of $90.8 \mathrm{~cm}^{3}$ yields an estimate of $0.363 \times 10^{14}$ synapses. The total number of human cerebellum Purkinje cells and granule cells are $28 \times 10^{6}$ (C.V. 0.16) 
and $109 \times 10^{9}$ (C.V. 0.17), respectively [Andreasen, 1996]. The number of synapses per Purkinje cell was early estimated as $8 \times 10^{5}$ neurons/cell [Black et al., 1990] but more recently as $1.74 \times 10^{5}$ [Napper, 2004]. Since the number of Purkinje cells $\left(28 \times 10^{6}\right)$ is small in relation to the number of granule cells $\left(109 \times 10^{9}\right)$, the high number of synapses per Purkinje cell $\left(1.74 \times 10^{5}\right)$ has minimal impact on the total number of synapses in the cerebellum (estimated as $0.363 \times 10^{14}$ synapses). Assuming the cerebellum has $109 \times 10^{9}$ neurons and $0.363 \times 10^{14}$ synapses, then each cerebellum granule cell would have only 333 synapses per granule cell, which seems very low when compared to the average 6,940 synapses per neuron in the human cerebral cortex [Tang et al., 2003]. The synapse-to-neuron ratio in rat cerebellar cortex is indeed reported have an average of 338 synapses per granule cell with a maximum of 707 synapses per granule cell [Warren and Bedi, 1989]. In rats the radical difference in the number of synapses per neuron from the frontal cortex to the cerebellum has been known for decades, with the frontal cortex having 22,270 $\pm 3,250$ synapses per neuron and the cerebellum having $495 \pm 25$ synapses per neuron [Bedi et al., 1980]. The number of neurons in the human neocortex is $\sim 4$ times smaller than the number of neurons in the human cerebellum [Azevedo et al., 2009], but since each cerebral cortex neuron has $\sim 16$ times more synapses per neuron than each cerebellum granule cell and the number of Purkinje cells is relatively low, the cerebral cortex seems to contribute $\sim$ four-fold more to the final estimate of the number of human brain synaptic processed bits per second. Taking the minimum synaptic density reported between $2-4 \times 10^{8} / \mathrm{mm}^{3}$ [Black et al., 1990] and the cerebellum volume of $90.8 \mathrm{~cm}^{3}$ [Andersen et al., 2003] we would obtain 1.82-3.63 x $10^{13}$ synapses, but assuming $(0.6903 \pm 0.0665) \times 10^{11}$ neurons [Azevedo et al., 2009] and 707 synapses per granulle cell [Warren and Bedi, 1989] implies 4.41-5.35 x $10^{13}$ synapses - so $(3.35 \pm 1.54) \times 10^{13}$ synapses seems a reasonable midrange value to adopt.

20. The average numbers of synapses per neuron in the cerebral cortex are estimated as $4.38 \times 10^{3}$ (occipital), $7.36 \times 10^{3}$ (parietal), $7.52 \times 10^{3}$ (temporal) and $7.48 \times 10^{3}$ (frontal) [Tang et al., 2003]. The total neocortex is estimated to average $6.94 \times 10^{3}$ synapses per neuron [Tang et al., 2003], thus for the frontal cortex the number of synapses would be $5.012 \times 10^{13}$ synapses, assuming $6.7 \times 10^{9}$ neurons [Pedersen, 2005] and 7.48 x $10^{3}$ synapses per neuron [Tang et al., 2003]), close to the $5.89 \times 10^{13}$ figure from [Tang et al., 2001, 2003].

21. Estimate based on neocortex percentages of the different types of electrophysiological types of neurons.

22. Assuming $6.94 \times 10^{3}$ synapses per neuron (as found in the human neocortex [Tang et al., 2003]) the (1.22 \pm $0.13) \times 10^{7}$ neurons would correspond to $(8.47 \pm 0.90) \times 10^{10}$ synapses.

23. Others have reported the percentages as $60.5 \%$ (irregular), $24 \%$ (tonic) and $15.5 \%$ (oscillatory) [RodriguezOroz et al., 2001].

24. Avoli [1994] estimated $63 \%$ of regular spiking neurons and $37 \%$ of bursting neurons. As no data was found for the percentage of fast-spiking neurons, we assumed a percentage of $3 \%$ based on the estimate of Steriade [1998] for the neocortex percentage of fast-spiking neurons, leaving $61 \%$ for regular spiking neurons and $36 \%$ for bursting neurons

25. The percentage of bursting neurons was estimated as $(3+6+7) /(6+28+19)=0.30$ [Tasker, 1991]. The percentage of regular spiking and fast spiking neurons are based on the proportions of electrophysiological types of neurons in the neocortex. 
26. Value for the subthalamic nucleus. Assuming number of neurons $5.61 \times 10^{5}$ and assuming an average of $6.94 \times 10^{3}$ synapses per neuron (as in the human cerebral cortex [Tang et al., 2003]), the subthalamus would have $3.89 \times 10^{9}$ synapses.

27. The human hypothalamus volume was reported as $4 \mathrm{~cm}^{3}$ [Hofman, 1997]. Assuming a neuron density of $(50.4 \pm 11.08) \times 10^{6} / \mathrm{cm}^{3}$ (similar to the neocortex), the total number of neurons in the human hypothalamus would be $(2.02 \pm 0.47) \times 10^{8}$ neurons. Assuming a synaptic density of $11.05 \times 10^{8}$ synapses $/ \mathrm{mm}^{3}$ ( \pm 0.41 S.E.M), the hypothalamus would have $4.42 \times 10^{12}$ synapses.

28. The human medulla oblongata volume was estimated as $5.7 \mathrm{~cm}^{3}$. Assuming a neuron density of $(50.4 \pm$ $11.08) \times 10^{6} / \mathrm{cm}^{3}$ (similar to the neocortex), the total number of neurons in the human midbrain is $(2.87 \pm$ $0.63) \times 10^{8}$ neurons. The medullary nuclei was estimated to have $1.3197 \times 10^{6}$ neurons [Porzionato et al., 2008]. Assuming an average of $(6.94 \pm 1.11) \times 10^{3}$ synapses per neuron (as in the human cerebral cortex [Tang et al., 2003]) we obtain an estimate of $(1.99 \pm 0.32) \times 10^{12}$ synapses.

29. The average brainstem volume was estimated as $34 \mathrm{~cm}^{3}$ [Ekinci et al., 2008]. The brainstem includes the medulla oblongata, the pons, and the midbrain. Total brainstem volume as well as pons and medulla have no age-related decline and both genders have similar total or regional brainstem volumes, averaging $\sim 4.7$ $\mathrm{cm}^{3}$ (midbrain), $\sim 19.1 \mathrm{~cm}^{3}$ (pons), and $\sim 5.7 \mathrm{~cm}^{3}$ (medulla). Assuming a neuron density of $(50.4 \pm 11.08) \mathrm{x}$ $10^{6} / \mathrm{cm}^{3}$ (similar to the neocortex), the total human brainstem population would be $(1.713 \pm 0.376) \times 10^{9}$ neurons. If we subtract the neuron counts estimated for the medulla oblongata $(2.87 \pm 0.63) \times 10^{8}$ and for the pons $(9.63 \pm 2.12) \times 10^{8}$, we obtain an estimate for the midbrain of $4.63 \times 10^{8}$ neurons; allocating this latter number equally into the three midbrain subregions (tectum, tegmentum, and pretectal region) gives $1.54 \times 10^{8}$ neurons for each. The midbrain thus has $(3.21 \pm 0.51) \times 10^{12}$ synapses assuming an average of $(6.94 \pm 1.11) \times 10^{3}$ synapses per neuron as in the human cerebral cortex [Tang et al., 2003]), also implying $(1.07 \pm 0.17) \times 10^{12}$ synapses for each of the three subregions. Taking midbrain volume to be $\sim 4.7 \mathrm{~cm}^{3}$ and assuming a neuron density of $(50.4 \pm 11.08) \times 10^{6} / \mathrm{cm}^{3}$ (similar to the neocortex), we obtain an estimate of $(2.37 \pm 0.52) \times 10^{8}$ neurons in the midbrain.

30. The average pons volume was estimated as $19.1 \mathrm{~cm}^{3}$ [Ekinci et al., 2008]. Assuming a neuron density of $(50.4 \pm 11.08) \times 10^{6} / \mathrm{cm}^{3}$ (similar to the neocortex), the human pons has $(9.63 \pm 2.12) \times 10^{8}$ neurons. Taking a synaptic density of $11.05 \times 10^{8}$ synapses $/ \mathrm{mm}^{3}( \pm 0.41$ S.E.M), the midbrain would have $2.11 \mathrm{x}$ $10^{13}$ synapses. Assuming an average of $(6.94 \pm 1.11) \times 10^{3}$ synapses per neuron (as in the human cerebral cortex [Tang et al., 2003]) the pons has $(6.68 \pm 1.06) \times 10^{12}$ synapses.

31. The basal ganglia has an estimated $(4.15 \pm 0.99) \times 10^{8}$ neurons [Karlsen and Pakkenberg, 2011]. Assuming an average of $6.94 \times 10^{3}$ synapses per neuron (as in the human cerebral cortex [Tang et al., 2003]) the human basal ganglia has a total of $(2.88 \pm 0.69) \times 10^{12}$ synapses.

32. The volume of the claustrum is is reported as $0.025 \%$ of the cerebral cortex, thus $\left(517 \mathrm{~cm}^{3}\right) / 400=1.29 \mathrm{~cm}^{3}$ [Crick and Kock, 2005][Kowianski et al., 1999][Nieuwenhuys, 2008]. Assuming a neuron density of (50.4 $\pm 11.08) \times 10^{6} / \mathrm{cm}^{3}$ (similar to the neocortex), the total number of neurons in the cerebral nuclei claustrum would be $6.50 \times 10^{7}$ neurons . Taking an average of $6.94 \pm 1.11 \times 10^{3}$ synapses per neuron (as in the human cerebral cortex [Tang et al., 2003]) for the clustrum implies a total of $(4.51 \pm 0.72) \times 10^{11}$ synapses.

33. The human cerebral nuclei has a volume between $44.7 \mathrm{~cm}^{3}$ [Pakkenberg and Gundersen, 1997] and $42.8 \mathrm{~cm}^{3}$ (0.13)[García-Fiñana, 2003]. At a neuron density of $(50.4 \pm 11.08) \times 10^{6} / \mathrm{cm}^{3}$ (similar to the neocortex) the 
neuron count in the human cerebral nuclei would be $(2.25 \pm 0.50) \times 10^{9}$. The estimated number of neurons for the anterior olfactory nucleus and the basal forebrain together is $1.76 \times 10^{9}$ neurons; allocating $10 \%$ to the anterior olfactory nucleus and $90 \%$ to the basal forebrain yields $1.58 \times 10^{9}$ neurons for the basal forebrain and $1.76 \times 10^{8}$ neurons for the anterior olfactory nucleus. Assuming an average of $(6.94 \pm 1.11) \times$ $10^{3}$ synapses per neuron (as in the human cerebral cortex [Tang et al., 2003]) we obtain $(1.10 \pm 0.18) \mathrm{x}$ $10^{13}$ synapses for the basal forebrain and $(1.22 \pm 0.20) \times 10^{12}$ synapses for the anterior olfactory nucleus.

These results for the quantity of electrical information processed in the whole human brain are very roughly in accord with previous estimates by Seitz, Merkle, Kurzweil, Malickas, Dix, and Fiala, but diverge significantly from estimates by Thagard, Hameroff and Tuszinsky mostly because these latter authors consider proteins and microtubules to be the relevant information processing units rather than neurons and synapses.

Note that $\mathrm{T}_{\mathrm{ss}}$ is the maximum event detection requirement for the entire embedded in vivo sensor system in the context of nanorobotic whole-brain monitoring. With population coding - an idea based on cortical lateral connections that has been used to implement an "ideal observer", that is, an optimal decoding of sensory information individual elements of information are represented not by the spiking activity of a single cell but rather by the activity of populations or clusters of neurons that strongly interact. Population codes can support computations such as noise removal and nonlinear mapping that might reduce total sensor burden since loss of information from a single cell may not significantly degrade the interpretation of overall spike activity.

\section{Conclusions}

This paper uses a novel electrophysiological approach to estimate the data rate requirements for acquiring, transmitting, and storing continuous real-time single-neuron electrical information from the human brain. We conclude that the task of monitoring raw data traffic for an entire living human brain, e.g., by employing in vivo neural nanorobotics systems, will require a network data handling capacity of $(5.52 \pm 1.13) \mathrm{x}$ $10^{16} \mathrm{bits} / \mathrm{sec}$, corresponding to an estimated synaptic-processed spike rate of $(4.31 \pm 0.86)$ $\mathrm{x} 10^{15}$ spikes/sec which is the event detection requirement for the entire embedded in vivo sensor system in the context of nanorobotic whole-brain monitoring. Non-electrical channels must also be recorded but the data processing requirements for these additional channels are expected to be far less demanding.

\section{Acknowledgments}

The principal author (NRBM) thanks the Fundação para a Ciência e Tecnologia (FCT) for their financial support of this work (grant SFRH/BD/69660/2010).

\section{References}

Adelman L. T., Bialek, W. and Olberg, R. M. [2003] The Information Content of Receptive Fields. Neuron, Vol. 40, 823-833, Cell Press. 
Allers K. A. and Sharp, T. [2003] Neurochemical and anatomical identification of fast- and slowfiring neurones in the rat dorsal raphe nucleus using juxtacellular labelling methods in vivo, Neuroscience 122 (2003), pp. 193-204.

Allman, J. M. [2010] The von Economo neurons in frontoinsular and anterior cingulate cortex in great apes and humans, Brain Struct Funct. 2010 Jun;214(5-6):495-517. Epub 2010 May 29.

Alonso-Nanclares, L., Kastanauskaite, A., Rodriguez, J., Gonzalez-Soriano, J. and DeFelipe, J. [2011] A Stereological Study of Synapse Number in the Epileptic Human Hippocampus, Front Neuroanat. 2011; 5: 8 .

Andreasen, N. C. [1996] Automatic Atlas-Based Volume Estimation of Human Brain Regions from MR Images, Journal of Computer Assisted Tomography: January/February 1996 - Volume 20 - Issue 1 - pp 98-106

Andersen B. B., Korbo, L., and Pakkenberg, B. [1992] A quantitative study of the human cerebellum with unbiased stereological techniques. J Comp Neurol 326: 549-560. (1992).

Andersen B. B., Gundersen, H. J., and Pakkenberg, B. [2003] Aging of the human cerebellum: a stereological study. J Comp Neurol.; 466: 356-365. 2003

Andersen, B. B. and Pakkenberg, B. [2003] Stereological quantitation in cerebella from people with schizophrenia, The British Journal of Psychiatry (2003) 182: 354-361. doi:10.1192/bjp.02.65

Anderson, J. R., Jones, B.W., Watt, C. B., Shaw, M. V., Yang, J. H., Demill, D., Lauritzen, J. S., Lin, Y., Rapp, K. D., Mastronarde, D., Koshevoy, P., Grimm, B. Tasdizen, T., Whitaker, R., Marc, R. E.[2011] Exploring the retinal connectome, Mol Vis. 2011 Feb 3; 17:355-79.

Astier, Y., Bayley, H. and Howorka, S. [2005] Protein components for nanodevices. Curr Opin Chem Biol. 2005 Dec;9(6):576-84.

Avoli, M. [1994] Electrophysiological and repetitive firing properties of neurons in the superficial/middle layers of the human neocortex maintained in vitro, Experimental Brain Research, Volume 98, Number 1, 135-144.

Azevedo, F. A., Carvalho, L. R., Grinberg, L. T., Farfel, J. M., Ferretti, R. E., Leite, R. E., Jacob Filho, W., Lent, R. and Herculano-Houzel, S. [2009] Equal numbers of neuronal and nonneuronal cells make the human brain an isometrically scaled-up primate brain. J. Comp Neurol. 513(5):532-41.

Barry, W. C., and Gutnickb, M. J. [1990] Intrinsic firing patterns of diverse neocortical neurons, Trends Neurosci. Mar;13(3):99-104.

Bean, B. P. [2007] The action potential in mammalian central neurons, Nature Reviews Neuroscience 8, 451-465. June 2007.

Bedi, K. S., Thomas, Y. M., Davies, C. A. and Dobbing, J. [1980] Synapse-to-neuron ratios of the frontal and cerebellar cortex of 30-day-old and adult rats undernourished during early postnatal life, The Journal of Comparative Neurology, Volume 193, Issue 1, pages 49-56, 1 Sept 1980

Beurrier, C., Congar, P., Bioulac, B., and Hammond, C. [1999] Subthalamic Nucleus Neurons Switch from Single-Spike Activity to Burst-Firing Mode, The Journal of Neuroscience, 15 January 1999, 19(2): 599-609.

Bialek, W., and Rieke, F. [1992] Reliability and information transmission in spiking neurons. Trends Neurosci. 1992 Nov;15(11):428-34.

Bialek, W. [1993] Bits and brains: Information flow in the nervous system. Physica A: Statistical Mechanics and its Applications, Volume: 200, Issue: 1-4, Pages: 581-593

Black, J. E., Isaacs, K. R., Anderson, B. J., Alcantara, A. A. and Greenough W. T. [1990] Learning causes synaptogenesis, whereas motor activity causes angiogenesis, in cerebellar cortex of adult rats, Proc. Nati. Acad. Sci. USA, Vol. 87, pp. 5568-5572.

Bliss, T. V. P., and Collingridge G. L., [1993] A synaptic model of memory: long-term potentiation in the hippocampus, Nature $361,31-39$.

Borst, A., and Theunissen, F. E. [1999] Information theory and neural coding, Nature neuroscience, Volume $2 \mathrm{n}^{\mathrm{o}} 11$, November 199. 
Bostrom N. [1998] How long before superintelligence?, Intl.Journal of Future Studies, 2, 1998

Braendgaard, H., Evans, S. M., Howard, C. V. and Gundersen, H. J. [1990] Total number of neurons in the human neocortex unbiasedly estimated using optical disectors. J Microsc 157, $285-304$.

Brenner, N. [2000] Synergy in a neural code, Neural Comput 12 (2000), pp. 1531-1552.

Brunjes, P. C., Illig, K. R. and Meyer, E. A. [2005] A field guide to the anterior olfactory nucleus (cortex), Brain Research Reviews, Volume 50, Issue 2, 15 December 2005, Pages 305-335.

Bundgaard, M. J. [2001] Size of neocortical neurons in control subjects and in Alzheimer's disease, Journal of Anatomy (2001), 198: 481-489.

Buracas, G. T. and Albright T. D. [1999] Gauging sensory representations in the brain. Trends Neurosci. Jul; 22(7):303-9.

Cavalcanti, A. and Freitas, R.A., Jr. [2003] Nanosystem Design with Dynamic Collision Detection for Autonomous Nanorobot Motion Control using Neural Networks, Computer Graphics and Geometry 5(2003):50-74. http://www.cgg-journal.com/2003-1/03.htm

Cavalcanti, A., Shirinzadeh, B., Freitas, R. A., Jr. and Hogg, T. [2008] Nanorobot Architecture for Medical Target Identification, Nanotechnology 19(January 2008):015103. http://www.iop.org/EJ/article/0957-4484/19/1/015103/nano8 1 015103.pdf

Cauli, B., Audinat, E., Lambolez, B., Angulo, M. C., Ropert, N., Tsuzuki, K., Hestrin, S. and Rossier, J. [1997] Molecular and physiological diversity of cortical nonpyramidal cells, $J$ Neurosci 17 (1997), pp.3894-3906.

Chang Y-M., and Luebke, J. I. [2007] Electrophysiological Diversity of Layer 5 Pyramidal Cells in the Prefrontal Cortex of the Rhesus Monkey: In Vitro Slice Studies, AJP - JN Physiol November 2007 vol. 98 no. 5 2622-2632

Colbert, C. M., and Johnston, D. [1996] Axonal action-potential initiation and $\mathrm{Na}+$ channel densities in the soma and axon initial segment of subicular pyramidal neurons. Journal of Neuroscience, 16, 6676-6686.

Connors, B.W., Gutnick, M. J. and Prince, D. A. [1982] Electrophysiological properties of neocortical neurons in vitro, J Neurophysiol 48 (1982), pp. 1302-1320.

Crick, F. C. and Koch, C [2005] What is the function of the claustrum? Phil. Trans. R. Soc. B (2005) 360, 1271-1279, doi:10.1098/rstb.2005.166

Crotty, P., Sangrey, T. and Levy, W. B. [2006] Metabolic Energy Cost of Action Potential Velocity, J. Neurophysiol 96: 1237-1246, 2006. March, 2006

DeFelipe, J. [1999] Estimation of the Number of Synapses in the Cerebral Cortex: Methodological Considerations, Cereb. Cortex (1999) 9 (7): 722-732. doi: 10.1093/cercor/9.7.722

Diego, C. [2004] Electrophysiological classes of neocortical neurons, Neural Networks Volume 17, Issues 5-6, Pages 633-646. June-July 2004.

Dix, A. [2007] The brain and the web: A quick backup in case of accidents. Interfaces, 65: 6-7.

Duijnhouwer, J., Remme, M. W. H., van Ooyen, A. and van Pelt, J. [2001] Influence of dendritic topology on firing patterns in model neurons. Neurocomputing 38-40: 183-189.

Eccles, J. [1957] The physiology of nerve cells (Baltimore, 1957)

Ekinci, N., Acer, N., Akkaya, A., Sankur, S., Kabadayi, T., Sahin, B. [2008] Volumetric evaluation of the relations among the cerebrum, cerebellum and brain stem in young subjects: a combination of stereology and magnetic resonance imaging. Surg Radiol Anat. 2008 Aug;30(6):489-94.

Faber, E. S. L., Callister, R. J. and Sah, P. [2001] Morphological and Electrophysiological Properties of Principal Neurons in the Rat Lateral Amygdala In Vitro, J Neurophysiol 85:714723.

Faulkner B. and Brown, T.H. [1999] Morphology and physiology of neurons in the rat perirhinallateral amygdala area, J. Comp Neurol 411 (1999), pp. 613-642.

Fiala, J. C. [2007] Synapses.Bu.Edu http://synapses.clm.utexas.edu/index.asp 
Fischer, C. P. [1999] Preferential loss of large neocortical neurons during HIV infection: a study of the size distribution of neocortical neurons in the human brain, Brain Research (1999) Volume: 828, Issue: 1-2, Pages: 119-126.

Foehring, R.C. [1990] Two patterns of firing in human neocortical neurons, Neurosci Lett. 1990 Mar 14;110(3):279-85.

Franceschetti, S., Guatteo, E., Panzica, F., Sancini, G., Wanke, E., and Avanzini, G. [1995] Ionic mechanisms underlying burst firing in pyramidal neurons: intracellular study in rat sensorimotor cortex, Brain Research 696 (1995) 127-139

Freitas, R.A., Jr. [1998] Exploratory Design in Medical Nanotechnology: A Mechanical Artificial Red Cell, Artif. Cells, Blood Subst., and Immobil. Biotech. 26:411-430. http://www.foresight.org/Nanomedicine/Respirocytes.html

Freitas, R.A., Jr. [1999] Nanomedicine, Volume I: Basic Capabilities (Landes Bioscience, Georgetown, TX). http:www.nanomedicine.com/NMI.htm

Freitas, R.A., Jr. [1999] Nanomedicine, Volume I: Basic Capabilities, (Landes Bioscience, Georgetown, TX, 1999), Chapter 4.8.6.1 Electric Field Neurosensing. http://www.nanomedicine.com/NMI/4.8.6.1.htm

Freitas, R.A., Jr. [2000] Nanodentistry, J. Amer. Dent. Assoc. 131(November 2000):1559-1566. http://jada.ada.org/cgi/content/full/131/11/1559\#SEC2

Freitas, R.A., Jr. [2003] Nanomedicine, Volume IIA: Biocompatibility (Landes Bioscience, Georgetown, TX) http://www.nanomedicine.com/NMIIA.htm

Freitas, R.A., Jr. [2005a] What is Nanomedicine? Nanomedicine: Nanotech. Biol. Med. http://www.nanomedicine.com/Papers/WhatIsNMMar05.pdf

Freitas, R.A., Jr. [2005b] Current Status of Nanomedicine and Medical Nanorobotics (Invited Survey), J. Comput. Theor. Nanosci. 2(March 2005):1-25. http://www.nanomedicine.com/Papers/NMRevMar05.pdf

Freitas, R.A., Jr. [2005c] Microbivores: Artificial Mechanical Phagocytes using Digest and Discharge Protocol,” J. Evol. Technol. 14(April 2005):1-52; orig. Zyvex preprint, March 2001. http://www.jetpress.org/volume14/freitas.html

Freitas, R.A., Jr. [2006a] Pharmacytes: An Ideal Vehicle for Targeted Drug Delivery,” J. Nanosci. Nanotechnol. 6(September/October 2006):2769-2775. http://www.nanomedicine.com/Papers/JNNPharm06.pdf

Freitas, R.A., Jr. [2006b] Chapter 13. Progress in Nanomedicine and Medical Nanorobotics, in Rieth, M., Schommers, W. (eds.) [2006] Handbook of Theoretical and Computational Nanotechnology, Volume 6 (Bioinformatics, Nanomedicine, and Drug Design, American Scientific Publishers, Stevenson Ranch, CA, 2006, pp. 619-672. http://www.nanomedicine.com/Papers/ProgressNM06.pdf

Freitas, R.A., Jr. [2007] The Ideal Gene Delivery Vector: Chromallocytes, Cell Repair Nanorobots for Chromosome Replacement Therapy, J. Evol. Technol. 16:1-97, http://jetpress.org/v16/freitas.pdf

Freitas, R.A., Jr. [2009] "Chapter 15. Computational Tasks in Medical Nanorobotics," in M.M. Eshaghian-Wilner, ed., Bio-inspired and Nano-scale Integrated Computing, John Wiley \& Sons, NY, pp. 391-428. http://www.nanomedicine.com/Papers/NanorobotControl2009.pdf

Freitas, R.A., Jr. [2010] Chapter 23. Comprehensive Nanorobotic Control of Human Morbidity and Aging, in Fahy, G.M., West, M. D., Coles, L. S. and Harris, S. B. (eds), The Future of Aging: Pathways to Human Life Extension (Springer, New York, 2010, pp. 685-805). http://www.nanomedicine.com/Papers/Aging.pdf

Freitas, R. A., Jr. and Merkle, R.C. [2004] Kinematic Self-Replicating Machines, (Landes Bioscience, Georgetown, TX, 2004). http://www.molecularassembler.com/KSRM.htm

Freitas, R.A., Jr. and Merkle, R.C. [2006] Nanofactory collaboration. http://www.molecularassembler.com/Nanofactory/ 
Freitas, R.A., Jr. and Phoenix, C.J. [2002] Vasculoid: A personal nanomedical appliance to replace human blood, J. Evol. Technol. 11(April 2002):1-139. http://www.jetpress.org/volume11/vasculoid.pdf

Fuhrmann, G., Segev, I., Markram, H. and Tsodyks, M. [2002] Coding of Temporal Information by Activity-Dependent Synapses, J. of Neurophysiology Vol. 87 No. 1 January 2002, pp. 140-148.

García-Fiñana, M. [2003] Comparison of MR imaging against physical sectioning to estimate the volume of human cerebral compartments, NeuroImage (2003) Volume: 18, Issue: 2, Publisher: Elsevier, Pages: $505-516$

Haas, H. L. [2008] Histamine in the Nervous System, Physiol Rev 88: 1183-1241.

Hamam B.N., Kennedy, T. E., Alonso, A. and Amaral, D. G. [2000] Morphological and electrophysiological characteristics of layer $\mathrm{V}$ neurons of the rat medial entorhinal cortex, $J$ Comp Neurol 418 (2000), pp. 457-472.

Hamam, B.N., Amaral, D. G. and Alonso, A. A. [2002] Morphological and electrophysiological characteristics of layer V neurons of the rat lateral entorhinal cortex, J Comp Neurol 451 (2002), pp. 45-61.

Hameroff S.R. [1987] Ultimate computing: Biomolecular consciousness and nanotechnology (Elsevier Science Publishers).

Hestrin S., and Armstrong, W.E. [1996] Morphology and physiology of cortical neurons in layer I, J. Neurosci 16 (1996), pp. 5290-5300.

Highley, J. R., Walker, M. A., Esiri, M. M., McDonald, B., Harrison, P. J. and Crow, T. J. [2001] Schizophrenia and the frontal lober: post-mortem stereological study of tissue volume, British journal of psychiatry (2001), 178, 337-343.

Hofman, M. A., [1997] Lifespan changes in the human hypothalamus, Experimental Gerontology, Vol. 32, Nos. 4/5, pp. 559-575, 1997.

Holtmaat, A. and Svoboda, K. [2009] Experience-dependent structural synaptic plasticity in the mammalian brain, Nat Rev Neurosci 10(9), 647-658 (2009).

Huttenlocher P. R. [1979] Synaptic density in human frontal cortex - Developmental changes and effects of aging. Brain Res. 1979 Mar 16;163(2):195-205.

IBM Seeks to Build the Computer of the Future Based on Insights from the Brain - IBM Awarded DARPA Funding for Cognitive Computing Collaboration. http://www03.ibm.com/press/us/en/pressrelease/26123.wss

Izhikevich E. M. [2004] Which model to use for cortical spiking neurons? IEEE Transactions on Neural Networks, 15: 1063-1070.

Juusola, M. [1996] Information processing by graded-potential transmission through tonically active synapses. Trends Neurosci. 1996 Jul;19(7):292-7.

Kandel, E.R., Schwartz, J. H. and Jessell, T. M. [2000] Principles of Neural Science (Fourth Edition)(New York, McGraw Hill).

Kandel, E.R. [2001] The molecular biology of memory storage: A dialogue between gene and synapses, Science 294 (5544): 1030-1038.

Karlsen, A. S., and Pakkenberg, B. [2011] Total Numbers of Neurons and Glial Cells in Cortex and Basal Ganglia of Aged Brains with Down Syndrome--A Stereological Study. Cerebral Cortex, 2011 - Oxford Univ Press

Kennedy, D. N., Lange, N., Makris, N., Bates, J., Meyer, J., Caviness, V. S., Jr. [1998] Gyri of the human neocortex: an MRI-based analysis of volume and variance. Cereb Cortex. 1998 Jun;8(4):372-84.

Kennedy, D. P. [2007] No reduction of spindle neuron number in frontoinsular cortex in autism, Brain and Cognition 64 (2007) 124-129.

Kleim, J. A. [2002] Synapse formation is associated with memory storage in the cerebellum, PNAS, October 1, 2002, vol. 99, no. 2

Kleinfeld, D., Bharioke, A., Blinder, P., Bock, D. D., Briggman, K. L., Chklovskii, D. B., Denk, 
W., Helmstaedter, M., Kaufhold, J. P., Lee, W. C., Meyer, H. S., Micheva, K. D., Oberlaender, M., Prohaska, S., Reid, R. C., Smith, S. J., Takemura, S., Tsai, P. S., Sakmann, B. [2011] Large-scale automated histology in the pursuit of connectomes. J Neurosci. 2011 Nov 9;31(45):16125-38.

Koch, C. [1983] Nonlinear interactions in a dendritic tree: localization, timing, and role in information processing. Proc Natl Acad Sci U.S.A. 1983 May;80(9):2799-802.

Koch, C. [1997] Biophysics of Computation: Information Processing in Single Neurons (Oxford University Press: New York, New York).

Koch, C. and Segev, I. [2000] The role of single neurons in information processing. Nature Neuroscience, 3 (suppl 1). pp. 1171-1177.

Kole, M. H. P., Letzkus, J. J., Stuart, G. J. [2007] Axon Initial Segment Kv1 Channels Control Axonal Action Potential Waveform and Synaptic Efficacy; Neuron. Aug 16;55(4):633-47.

Kostarelos K. [2010] Nanorobots for medicine: how close are we? Nanomedicine (Lond). 2010 Apr;5(3):341-2.

Kowianski, P., Dziewiatkowski, J., Kowianska, J. and Morys, J. [1999] Comparative anatomy of the claustrum in selected species: a morphometric analysis. Brain Behav. Evol. 53, 44-54.

Kreczmanski, P. [2007] Volume, neuron density and total neuron number in five subcortical regions in schizophrenia. Brain (2007) 130 (3): 678-692. doi: 10.1093/brain/awl386

Kurzweil R. [1999] The age of spiritual machines. New York: Viking, page 77.

Kuwana, S., Tsunekawa, N., Yanagawa, Y., Okada, Y., Kuribayashi, J. and Obata, K. [2006] Electrophysiological and morphological characteristics of GABAergic respiratory neurons in the mouse pre-Botzinger complex, Eur J Neurosci23(2006), pp.667-674.

Kuzum, D., Jeyasingh, R. G., Lee, B. and Wong, H. S. [2011] Nanoelectronic Programmable Synapses Based on Phase Change Materials for Brain-Inspired Computing. American Chemical Society, Nano Lett, June 14, 2011.

Lee, S. H., Govindaiah, G. and Cox, C. L. [2007] Heterogeneity of firing properties among rat thalamic reticular nucleus neurons, J Physiol 582 (2007), pp. 195-208.

Lee, S. H., Choi, J. H., Lee, N., Lee, H. R., Kim, J. I., Yu, N. K., Choi, S. L., Lee, S. H., Kim, H. and Kaang, B. K. [2008] Synaptic protein degradation underlies destabilization of retrieved fear memory. Science. 2008 Feb 29;319(5867):1253-6. Epub 2008 Feb 7.

Lionel, G. N., Azouz, R., Sanchez-Vives, M. V., Gray, C. M. and McCormick, D. A. [2003] Electrophysiological Classes of Cat Primary Visual Cortical Neurons In Vivo as Revealed by Quantitative Analyses, AJP - JN Physiol vol. 89 no. 3 1541-1566.

Llinas, R., and Ribary, U. [1993] Coherent 40-Hz oscillation characterizes dream state in humans; Proc Natl Acad Sci U S A. 90(5): 2078-2081.

London, M. and Hausser, M. [2005] Dendritic Computation, Annual Review of Neuroscience, Vol. 28: 503-532. July 2005.

Lu, J., Tapia, J. C., White, O. L., Lichtman, J. W. [2009] The Interscutularis Muscle Connectome. PLoS Biol. 2009 Feb 10;7(2):e32

Maas, W. [1999] Dynamic Stochastic Synapses as Computational Units, Neural Computation, May 15, 1999, Vol. 11, No. 4, Pages 903-917. http://zadorlab.cshl.edu/PDF/Maass-Zador99.pdf

Malickas, A. [1996] Gradual uploading as a cognition of mind. http://www.aleph.se/Trans/Global/Uploading/gupload.html

Mallouk, T. E., and Sen, A. [2009] Powering nanorobots. Sci Am. 2009 May;300(5):72-7.

Manwani, A. [2001] Detecting and estimating signals over noisy and unreliable synapses: Information-theoretic analysis. Neural Comput. 2001 Jan;13(1):1-33.

Marcus, D. S., Harwell, J., Olsen, T., Hodge, M., Glasser, M. F., Prior, F., Jenkinson, M., Laumann, T., Curtiss, S. W., and Van Essen, D. C. [2011] Informatics and data mining tools and strategies for the human connectome project. Front Neuroinform. 2011;5:4

Markram, H. [1998] Interneurons of the Neocortical Inhibitory System; AJP - JN Physiol January 
1998 vol. 79 no. $1483-490$.

Martel, S., Mohammadi, M., Felfoul, O., Lu, Z. and Pouponneau, P. [2009] Flagellated Magnetotactic Bacteria as Controlled MRI-trackable Propulsion and Steering Systems for Medical Nanorobots Operating in the Human Microvasculature. Int $J$ Rob Res. 2009 Apr 1;28(4):571-582.

Mavroides, D. and Ferreira, A. (eds.) [2011] NanoRobotics: Current Approaches and Techniques, (Springer, New York, 2011).

McGann, J.P., Moyer, J. R. Jr. and Brown, T. H. [2001] Predominance of late-spiking neurons in layer VI of rat perirhinal cortex, $J$ Neurosci 21ß (2001), pp. 4969-4976.

Merkle, R. [1989] Energy limits to the computational power of the human brain. Foresight Update No. 6, August.

Moravec, H. [1998] When will computer hardware match the human brain? Journal of Evolution and Technology, 1, 1998.

Morris, K. [2001] Macrodoctor, come meet the nanodoctors. Lancet. 10;357(9258):778.

Nambu, A. and Llinas, R. [1997] Morphology of globus pallidus neurons: its correlation with electrophysiology in guinea pig brain slices, J Comp Neurol 377 (1997), pp. 85-94.

Napper, R. M. A. [2004] Number of parallel fiber synapses on an individual Purkinje cell in the cerebellum of the rat, The Journal of Comparative Neurology, Volume 274, Issue 2, pages 168-177, 8 August 1988.

Nieuwenhuys R. [2008] The human central nervous system (Springer, 2008).

Nishida, S., Narumoto, J., Sakai, Y., Matsuoka, T., Nakamae, T., Yamada, K., Nishimura, T. and Fukui, K. [2011] Anterior insular volume is larger in patients with obsessive-compulsive disorder. Progress in Neuro-Psychopharmacology and Biological Psychiatry 35:4, 997-1001.

Ogawa, Y., and Rasband, M. N. [2008] The functional organization and assembly of the axon initial segment; Volume 18, Issue 3, June 2008, Pages 307-313.

Pakkenberg, B. [1993] Total nerve cell number in neocortex in chronic schizophrenics and controls estimated using optical disectors; Biological Psychiatry,Vol. 34,No.11, 1 Dec 1993, 768-772

Pakkenberg, B., and Gundersen, H. J. [1997] Neocortical Neuron Number in Humans: Effect of Sex and Age, J Comp Neurol 384:312-320. 1997

Pakkenberg, B. [2003] Aging and the human neocortex, Exp. Gerontol. 38 (1/2) (2003), pp. 95-99.

Palmer L. M., and Stuart, G. J. [2006] Site of Action Potential Initiation in Layer 5 Pyramidal Neurons, The Journal of Neuroscience, February 8, 2006, 26(6):1854-1863;

Palay, S. L., Sotelo, C., Peters, A. and Orkand, P. M. [1968] The Axon Hillock And The Initial Segment. The Journal of Cell Biology, Vol 38, 193-201, 1968.

Pang, K., Tepper, J.M., and Zaborszky L. [1998] Morphological and Electrophysiological Characteristics of Noncholinergic Basal Forebrain Neurons, The journal of comparative neurology, 394:186-204 (1998)

Park, H. H., Jamison, A. C. and Lee, T. R. [2007] Rise of the nanomachine: the evolution of a revolution in medicine. Nanomedicine (Lond). 2007 Aug;2(4):425-39.

Patel, G.M., Patel, G.C., Patel, R.B., Patel, J.K. and Patel, M.[2006] Nanorobot: a versatile tool in nanomedicine. J Drug Target. 2006 Feb; 14(2):63-7.

Penrose R. [1989] The emperor's new mind (New York: Oxford University Press).

Pedersen, K. M. [2005] No global loss of neocortical neurons in Parkinson's disease: A quantitative stereological study. Movement disorders [0885-3185] Pedersen ano: 2005, 20.2, p. 164

Pelvig, D. P., Pakkenberg, H., Regeur, L., Oster, S. and Pakkenberg, B. [2003] Neocortical glial cell numbers in Alzheimer's disease; a stereological study; Dement Geriatr Cogn Disord 2003;16:212-219, doi: 10.1159/000072805.

Pereira, P. M. G., Insaustid, R., Artacho-Pérulad, E, Salmenperäe, T., Kälviäinene, R., and Pitkänenf, A. [2005] MR Volumetric Analysis of The Piriform Cortex and Cortical Amygdala in Drug-Refractory Temporal Lobe Epilepsy, American Journal of Neuroradiology 26:319- 
332, February 2005.

Plenz, D. and Kitai, S. T. [1998] Up and Down States in Striatal Medium Spiny Neurons Simultaneously Recorded with Spontaneous Activity in Fast-Spiking Interneurons Studied in Cortex-Striatum-Substantia Nigra Organotypic Cultures, The Journal of Neuroscience, 1 January 1998, 18(1): 266-283.

Polavieja, G. G., Harsch, A., Kleppe, I., Robinson, H. P C., and Juusola, M. [2005] Stimulus History Reliably Shapes Action Potential Waveforms of Cortical Neurons; J Neurosci. 2005 Jun 8;25(23):5657-65.

Popov, A. M., Lozovik, Y. E., Fiorito, S. and Yahia, L. [2007] Biocompatibility and applications of carbon nanotubes in medical nanorobots, Int J Nanomedicine. 2007;2(3):361-72.

Porzionato, A., Macchi, V., Guidolin, D., Sarasin, G., Parenti, A. and De Caro, R.[2008] Anatomic distribution of apoptosis in medulla oblongata of infants and adults, J Anat. 2008 February; 212(2): 106-113.

Puro, D. G., De Mello, F. G. and Nirenberg, M. [1997] Synapse turnover: the formation and termination of transient synapses; Proc Natl Acad Sci U S A. 1977 November; 74(11): 49774981.http://www.pnas.org/content/74/11/4977.abstract

Raz A., Vaadia, E. and Bergman, H. [2000] Firing Patterns and Correlations of Spontaneous Discharge of Pallidal Neurons in the Normal and the Tremulous 1-Methyl-4-Phenyl-1,2,3,6Tetrahydropyridine Vervet Model of Parkinsonism. J Neurosci. 2000 Nov 15;20(22):8559-71.

Raz, N. [2004] Aging, sexual dimorphism, and hemispheric asymmetry of the cerebral cortex: replicability of regional differences in volume, Neurobiol Aging. 2004, Mar;25(3):377-96.

Likhtik, E., Pelletier, J. G., Popescu, A. T. and Paré, D. [2006] Identification of Basolateral Amygdala Projection Cells and Interneurons Using Extracellular Recordings, JN Physiol December 2006 vol. 96 no. 6 3257-3265.

Rieke, F., Warland, D., deRuyter, and Bialek, W. [1997] Spikes: Exploring the Neural Code (Cambridge, MA: MIT Press)

Rodriguez-Oroz, M. C., Rodriguez, M., Guridi, J.k Mewes, K., Chockkman, V., Vitek, J., Delong, M. R. and Obeso, J. A. [2001] The subthalamic nucleus in Parkinson's disease: somatotopic organization and physiological characteristics; Brain (2001) 124 (9): 1777-1790. doi: 10.1093/brain/124.9.1777

Rollenhagen, A. and Lübke, J. H. R. [2006] The morphology of excitatory central synapses: from structure to function, Cell Tissue Res (2006) 326:221-237n. http://www.springerlink.com/content/dl70582541203r82/fulltext.pdf

Rollenhagen, A., Satzler, K., Rodriguez, E. P., Jonas, P., Frotscher, M. and Lubke, J. H. R. [2007] Structural determinants of transmission at large hippocampal mossy fiber synapses. $J$ Neurosci. 2007 Sep 26;27(39):10434-44.

Sandberg, A. and Bostrom, N. [2008] Whole Brain Emulation: A Roadmap, Technical Report \#2008.3, Future of Humanity Inst., Oxford University, www.fhi.ox.ac.uk/reports/2008-3.pdf.

Sarpeshka, R. [1997] Efficient Precise Computation with Noisy Components: Extrapolating From an Electronic Cochlea to the Brain. California Institute of Technology, Pasadena, California 1997. PhD Thesis http://www.rle.mit.edu/avbs/documents/thesis.pdf

Sarpeshka, R. [1998] Analog Versus Digital: Extrapolating from Electronics to Neurobiology; Neural Computation archive Volume 10 Issue 7, Oct. 1998. http://www.rle.mit.edu/avbs/publications/journal papers/analog vs digital.pdf

Scorcioni, R. Lazarewicz, M. T., Ascoli, G. A. [2004] Quantitative Morphometry of Hippocampal Pyramidal Cells: Differences between Anatomical Classes and Reconstructing Laboratories; Ascolithe Journal Of Comparative Neurology 473:177-193.

Schumann, C. M. and Amaral, D. G. [2005] Stereological Estimation of the Number of Neurons in the Human Amygdaloid Complex, J Comp Neurol. 2005 October 31; 491(4): 320-329.

Seitz, B. T. [2007] The great gray ravelled knot. Secondary Titl. 
http://hiqnews.megafoundation.org/The Great Gray Ravelled Knot.htm

Seun, H. S. [2011] Towards functional connectomics, 170, Nature, Vol 471, 10 March 2011.

Simic, G., Kostovic, I., Winblad, B. and Bogdanovic, N. [1997] Volume and number of neurons of the human hippocampal formation in normal aging and Alzheimer's disease. J Comp Neurol. 1997 Mar 24;379(4):482-94.

Sporns, O., Tononi, G., Kötter, R. [2005] The Human Connectome: A Structural Description of the Human Brain. PLoS Comput Biol 1(4): e42. doi:10.1371/journal.pcbi.0010042.

Staiger, J. F., Flagmeyer, I., Schubert, D., Zilles, K., Kotter, R. and Luhmann, H. J. [2004] Functional diversity of layer IV spiny neurons in rat somatosensory cortex: quantitative morphology of electrophysiologically characterized and biocytin labeled cells, Cereb Cortex 14 (2004), pp. 690-701.

Steriade, M., Timofeev, I., Durmuller, N. and Grenier, F. [1998] Dynamic Properties of Corticothalamic Neurons and Local Cortical Interneurons Generating Fast Rhythmic (30-40 Hz) Spike Burst, J Neurophysiol. 1998 Jan;79(1):483-90.

Steriade, M., Timofeev, I. and Grenier, F. [2001] Natural Waking and Sleep States: A View From Inside Neocortical Neurons. JN Physiol vol. 85 no. 5 1969-1985.

Steriade, M. [2004] Neocortical Cell Classes Are Flexible Entities; Nature reviews. Neuroscience, vol.:5 iss:2 pág.:121.

Strong S. P., Koberle, R., van Steveninck, R. R. de R. and Bialek, W. [1998] Entropy and Information in Neural Spike Trains. Physical review letters, Volume 80, number 1. 197-200.

Stuart, G. J., and Sakmann, B. [1994] Active propagation of somatic action potentials into neocortical pyramidal cell dendrites. Nature, 367, 69- 72.

Takakusaki, K., Shiroyama, T. and Kitai, S. T. [1997] Two types of cholinergic neurons in the rat tegmental pedunculopontine nucleus: electrophysiological and morphological characterization, Neuroscience 79 (1997), pp. 1089-1109.

Tang, Y., Nyengaard, J. R., De Groot, D. M. and Gundersen, H. J. [2001] Total regional and global number of synapses in the human brain neocortex. Synapse 41 (3), 258-273.

Tang, Y., Nyengaard, J. R., Pakkenberg, B. and Gundersen, H. J. [2003] Stereology of neuronal connections (myelinated fibers of white matter and synapses of neocortex) in human brain, Image Anal Stereol. 2003;22:171-182.

Tasker, J. G. and Dudek, F. E. [1991] Electrophysiological Properties of Neurones in the Region Of The Paraventricular Nucleus in Slices of Rat Hypothalamus, Journal of Physiology (1991), 434, pp. 271-293 271

Tavares, A. [2006] Padrões De Descarga Neuronal Na Região De CA1 Do Hipocampo De Pacientes Com Epilepsia Do Lobo Temporal E De Ratos Com Epilepsia Induzida Pela Pilocarpina: Um Estudo Comparativo, Universidade Federal do Rio Grande do Sul. http://www.lume.ufrgs.br/bitstream/handle/10183/11246/000610518.pdf

Thagard, P. [2002] How molecules matter to mental computation, Philosophy of Science, 69: 429-446, page 442.

Tuszynski J. [2006] The dynamics of c-termini of microtubules in dendrites: A possible clue for the role of neural cytoskeleton in the functioning of the brain. Journal of Geoethical Nanotechnology, http://www.aleph.se/Trans/Individual/Cryonics/neurosusp upload.txt.

Türe, U., Yaşargil, D. C., Al-Mefty, O. and Yaşargil, M. G. [1999] Topographic anatomy of the insular region, Journal of Neurosurgery, April 1999 / Vol. 90 / No. 4 / Pages 720-733.

Von Neumann, J. [1958] The Computer and The Brain (Yale University Press)

Wang, Z. and McCormick D. A. [1993] Control of firing mode of corticotectal and corticopontine layer $\mathrm{V}$ burst-generating neurons by norepinephrine, acetylcholine, and 1S,3R- ACPD. $J$ Neurosci. 1993 May;13(5):2199-216.

Wang, X. J. [1999] Fast burst firing and short-term synaptic plasticity: A model of neocortical chattering neurons. Neuroscience. 1999 Mar;89(2):347-62. 
Warren, M. A. and Bedi, K. S. [1989] Synapse-to-neuron ratios in rat cerebellar cortex following lengthy periods of undernutrition, J. Anat. (1990), 170, pp. 173-182 173

Weiss, T. and Veh, R.W. [2011] Morphological and electrophysiological characteristics of neurons within identified subnuclei of the lateral habenula in rat brain slices, Neuroscience Volume 172, 13 January 2011, Pages 74-93

West, M. J. and Gundersen, H. J. G. [1990] Unbiased stereological estimation of the number of neurons in the human hippocampus, The Journal of Comparative Neurology, Volume 296, Issue 1, pages 1-22, 1 June 1990

Wilson, C. J. [1981] Spontaneous firing patterns of identified spiny neurons in the rat neostriatum. Brain Res. 1981 Sep 7;220(1):67-80.

Wilson, F. A., O’Scalaidhe, S. P. and Goldman-Rakic, P. C. [1994] Functional synergism between putative y-aminobutyrate-containing neurons and pyramidal neurons in prefrontal cortex, Proc Natl Acad Sci U S A. 1994 April 26; 91(9): 4009-4013.

Wilson, H. R. [1999] Simplifed Dynamics of Human and Mammalian Neocortical Neurons. Journal of Theoretical Biology. Volume 200, Issue 4, Pages 375-388.

Wu S. H. and Kelly, J.B. [1995] In vitro brain slice studies of the rat's dorsal nucleus of the lateral lemniscus: II. Physiological properties of biocytin-labeled neurons, J. Neurophysiol 73 (1995), pp. 794-809.

Xu, H., Pan, F., Yang, G. and Gan, W. [2007] Choice of cranial window type for in vivo imaging affects dendritic spine turnover in the cortex. Nature Neuroscience 10, 549 - 551.

Zachary, F. [1996] Influence of dendritic structure on firing pattern in model neocortical neurons. Nature 382, $363-366$.

Zador, A. [1998] Impact of Synaptic Unreliability on the Information Transmitted by Spiking Neurons. JN Physiol vol. 79 no. 3 1219-1229. March 1998.

Zhang, X. [2008] A Mathematical Model of a Neuron with Synapses based on Physiology; Nature Proc.:21Mar2008,http://precedings.nature.com/documents/1703/version/1/files/npre20081703 $\underline{-1 . p d f}$. 